Circulating Biomarkers in Head and Neck Cancer Patients and the Influence of Cigarette Smoking

Bengt-Åke Andersson 


\title{
Circulating Biomarkers in Patients with Head and Neck Cancer and the Influence of Cigarette Smoking
}

\author{
Bengt-Åke Andersson
}

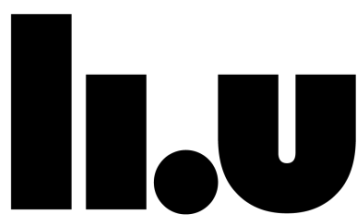

LINKÖPING UNIVERSITY

Laboratory medicine, Jönköping, Region Jönköping County

Linköping University

Department of Clinical and Experimental Medicine

SE-581 83 Linköping

Sweden

Linköping 2019 
(C)Bengt-Åke Andersson, 2019

Published articles have been reprinted with the permission of the copyright holders.

Printed in Sweden by LiU-Tryck, Linköping, Sweden, 2019

ISBN 978-91-7929-953-8

ISSN 0345-0082 


\section{Abstract}

Head and neck cancer (HNC) is a collective name for heterogeneous tumors located in the head and neck regions for which smoking, alcohol and human papillomavirus (HPV) are documented risk factors. The survival of HNC patients has only improved marginally during the last decade. The most important prognostic factors are tumor size, local spread and distant metastases, tumor node metastasis (TNM) staging. Prognostic biomarkers are needed as a complement to TNM staging.

The aim for this thesis was to investigate rapid and low cost blood based biomarkers which could indicate the risk of $\mathrm{HNC}$, recurrence of the disease or the survival of HNC patients. Furthermore, the aim was to examine how cigarette smoking influences the levels of biomarkers.

In paper I, a possible role of plasma cytokines or proteins associated with immune response or inflammation, as biomarkers for the survival of HNC patients was investigated. Higher levels of C-reactive protein (CRP) and tumor necrosis factor alpha (TNF- $\alpha$ ) were detected in plasma of the patients compared with the levels in the controls. The elevated levels of these two biomarkers detected in patients were associated with decreased survival.

In paper II, the influence of 45 single nucleotide polymorphisms (SNPs) located in 41 genes associated with cell cycle progression, cell death, DNA repair or immune response on cancer risk, tumor recurrence and survival in HNC patients were investigated. SNPs in immune response genes were associated with risk for $\mathrm{HNC}$, an elevated risk for recurrence and a decreased survival in HNC patients.

In paper III, the influence of cigarette smoking on levels of inflammatory cells, proteins or cytokines/chemokines, microRNAs (miRNAs) and SNPs was analysed in healthy smokers and non-smokers. Higher levels of total white blood cells (WBCs), neutrophils, monocytes, lymphocytes, neutrophil to lymphocyte ratio (NLR), CRP, monocyte chemoattractant protein1 (MCP-1) and interferon gamma (IFN- $\gamma$ ) were detected in smokers compared to non-smokers and indicate an inflammatory response. Also, a lower level of oncomiRNA miR-21was detected in smokers. This alteration, in combination with the elevated levels of IFN- $\gamma$ in smokers could be a protective response to cigarette smoke. The higher levels of IFN- $\gamma$ in smokers compared to non-smokers were however only detected in individuals with SNP rs2069705 genotype AG/GG. This indicates a genetic association of the levels of IFN- $\gamma$. 
In paper IV, the separate effects of cigarette smoking and HNC on inflammatory or immune biomarkers and the impact of high risk human papillomavirus, age and gender were investigated. Comparisons of circulating levels of WBCs and its subpopulations, plasma proteins or cytokines/chemokines between smoking and non-smoking patients, smoking and non-smoking controls and between the patient and control groups were analysed. Smoking had highest impact on elevated levels of WBCs, IFN- $\gamma$ and MCP-1, and HNC had highest impact on elevated levels of neutrophils, monocytes, NLR, CRP, macrophage inflammatory protein 1 beta and TNF- $\alpha$.

In conclusion, host immune response associated parameters could be suitable as biomarkers for the risk of $\mathrm{HNC}$, risk of recurrence or in predicting survival of HNC patients. This thesis show that HNC are associated with systemic inflammatory response and upregulated CRP and TNF- $\alpha$ is related to shorter survival in HNC patients. Additionally, SNPs in immune response genes such as rs1800629 in the TNF- $\alpha$ gene indicates a risk for HNC or an elevated risk for recurrence and a decreased survival in HNC patients. These rapid and low cost blood based biomarkers could be used in combination or as a supplement to established biomarkers in the clinic for a more personalized treatment modality. 


\section{Biomarkörer vid Huvud- och halscancer}

Huvud- och halscancer (HH-cancer) innefattar tumörer belägna i huvud och halsområdet. Tobaksrökning ökar risken dramatiskt för olika sjukdomar. Knappt hälften av rökande patienter dör i de av rökning orsakade sjukdomarna. Cancer är orsaken till en tredjedel av de rökrelaterade dödsfallen av vilka HH-cancer är en. En andel av patienterna med HH-cancer dör på grund av att tumören varit för stor redan vid diagnos eller att tumören har spridit sig till övriga delar av kroppen. Men för många patienter är det mycket oklart vad som bestämmer behandlingsresultatet. Tumörerna är till synes lika och behandlingen standardiserad.

Målet med denna doktorsavhandling var att undersöka billiga och lättillgängliga biologiska markörer som kan indikera risk för att drabbas av HH-cancer eller om dessa markörer kan förutspå behandlingsresultat och överlevnad hos de drabbade patienterna. Dessutom undersöktes hur cigarettrökning påverkade nivåerna av markörerna.

I studie I, undersöktes om molekyler i blodet (biomarkörer), förknippade med immunförsvaret, kunde förutsäga överlevnaden hos $\mathrm{HH}$-cancerpatienter. I jämförelse med friska individer sågs högre nivåer av molekylerna TNF- $\alpha$ och CRP hos patienterna och dessa förhöjningar var relaterade till förkortad överlevnad hos patienterna.

I studie II, var målet att undersöka om variationer i gener, förknippade med immunförsvaret, celldelning, celldöd eller enzymer som reparerar skadat DNA, kunde påverka risk och prognos för HH-cancer. Resultatet visade framför allt att små ärftliga variationer i gener som reglerar immunförsvaret kunde påverkade risk för HH-cancer, risk för återfall i sjukdomen samt överlevnaden hos patienterna.

I studie III, jämfördes inflammatoriska och immunförknippade biomarkörer som kunde påverkas av cigarettrökning mellan friska rökare och friska icke-rökare. Rökarna hade en högre inflammatorisk aktivitet med högre nivåer av totalt antal vita blodkroppar och tre av dess olika undergrupper (neutrofiler, monocyter och lymfocyter) samt av biomarköerna CRP, MCP-1 och IFN- $\gamma$. De funna lägre nivåerna av den cancerförknippade biomarkören miR-21 och högre nivåer av den förmodat skyddande biomarkören IFN- $\gamma$ hos rökarna, kan vara ett uttryck för kroppens försvar mot den cancerframkallade cigarettröken. Ärftliga faktorer tycks kunna påverka de högre nivåerna av IFN- $\gamma$ hos rökarna, eftersom ökningen endast fanns i en grupp individer med viss typ av genetisk uppsättning. 
Eftersom både rökning och HH-cancer ger upphov till inflammation, undersöktes i studie IV hur dessa var för sig påverkade nivåerna av inflammatoriska biomarkörer. Detta för en bättre förståelse hur immunförsvaret reagerar på rökning och HH-cancer. Jämförelser av inflammatoriska markörer från rökande och icke-rökande patienter, och rökande och ickerökande friska individer genomfördes. Rökning hade störst påverkan på de högre nivåerna av totalt antal vita blodkroppar och signalmolekylerna MCP-1 och IFN- $\gamma$. HH-cancer hade störst påverkan på högre nivåerna av neutrofiler, monocyter, kvoten mellan neutrofiler och lymfocyter, CRP, MIP-1b och TNF- $\alpha$.

Uppkomsten av HH-cancer, behandlingsresultat och överlevnad bland patienterna kan antas inte bara bero på tumörens egenskaper, utan även på värdfaktorer hos patienten. Dessa kan vara ärftliga, eller bero på reglering av gener eller tumörens omgivning av t.ex. immunceller och inflammatoriska molekyler och hur dessa samverkar med miljöfaktorer som tobaksrökning. I denna avhandling presenteras biomarkörer som kan bidra med information om risk och prognos för $\mathrm{HH}$-cancer samt hur tobaksrökning påverkar dessa markörer. 


\section{Original papers}

This thesis is based on the following papers:

I. Andersson B̊̊, Lewin F, Lundgren J, Nilsson M, Rutqvist LE, Löfgren S, Laytragoon-Lewin N. Plasma tumor necrosis factor- $\alpha$ and C-reactive protein as biomarker for survival in head and neck squamous cell carcinoma. J Cancer Res Clin Oncol. 2014 Mar;140(3):515-9.

II. Laytragoon-Lewin N, *Cederblad L, *Andersson BÅ, *Olin M, Nilsson M, Rutqvist LE, Lundgren J, Engström M, Tytor W, Löfgren S, Lewin F. Single-Nucleotide Polymorphisms and Cancer Risk, Tumor Recurrence, or Survival of Head and Neck Cancer Patients. Oncology. 2017;92(3):161-169.

* The authors have contributed equally to this work.

III. Andersson B̊̊, Sayardoust S, Löfgren S, Rutqvist LE, Laytragoon-Lewin N. Cigarette smoking affects microRNAs and inflammatory biomarkers in healthy individuals and an association to single nucleotide polymorphisms is indicated. Biomarkers. 2019 Mar;24(2):180-185.

IV. Andersson BÅ, Löfgren S, Lewin F, Nilsson M, Laytragoon-Lewin N. Impact of Cigarette Smoking and Head and Neck Squamous Cell Carcinoma on Circulating Inflammatory Biomarkers. Oncology. 2019 Aug 22:1-6. [Epub ahead of print]. 


\section{Abbreviations}

APC

CI

CVD

CRP

DC

EBV

ELISA

FFPE

GM-CSF

HNSCC

HNC

HPV

HR-HPV

IFN- $\gamma$

IL

MIP-1 $\beta$

miRNA

MCP-1

MDSC

NK

NLR

PDGF-BB

PPP

SNP

Th

T-cell

TMB

T-reg
Antigen-presenting cell

Confidence interval

Cardiovascular disease

C-reactive protein

Dendritic cell

Epstein-Barr virus

Enzyme-linked immunosorbent assay

Formalin-fixed paraffin-embedded

Granulocyte-macrophage colony-stimulating factor

Head and neck squamous cell carcinoma

Head and neck cancer

Human papillomavirus

High risk human papillomavirus

Interferon gamma

Interleukin

Macrophage inflammatory protein-1 beta

MicroRNA

Monocyte chemoattractant protein-1

Myeloid-derived suppressor cell

Natural killer

Neutrophil to lymphocyte ratio

Platelet-derived growth factor-BB

Purchasing power parity

Single nucleotide polymorphism

T-helper

T-lymphocyte

Tumor mutation burden

T-regulatory 
TME

TNF- $\alpha$

TNM

pTNM

WBC
Tumor microenvironment

Tumor necrosis factor alpha

Tumor Node Metastasis

Pathological Tumor Node Metastasis

White blood cell 


\section{Contents}

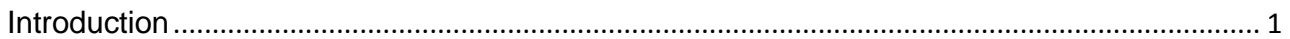

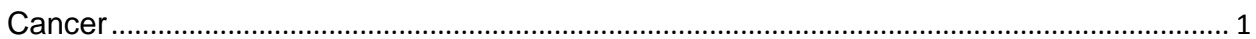

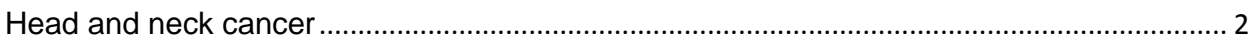

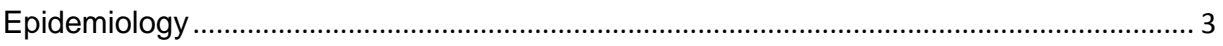

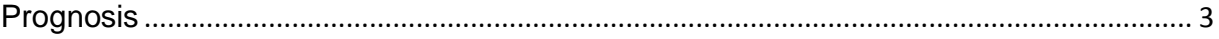

Treatment

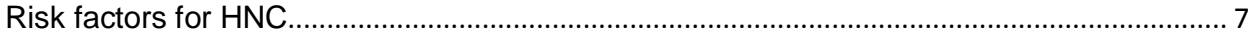

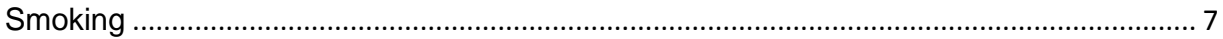

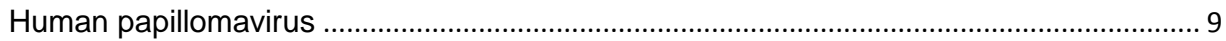

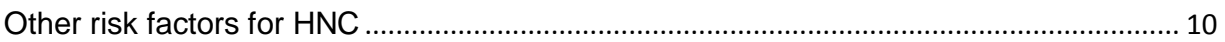

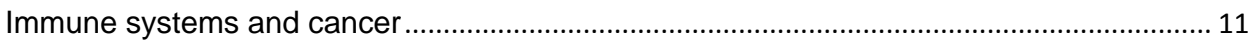

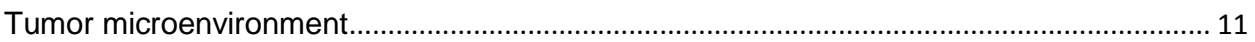

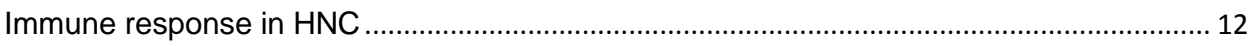

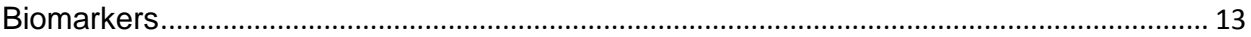

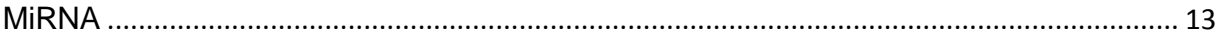

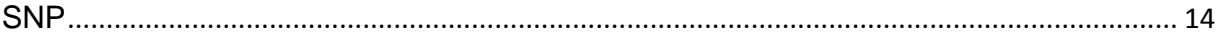

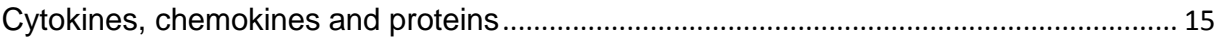

General aims

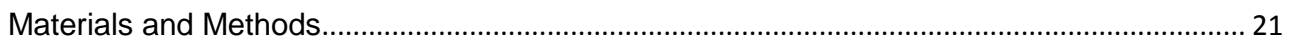

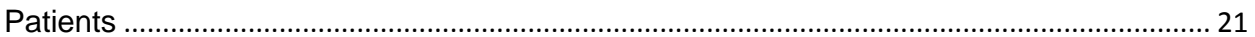

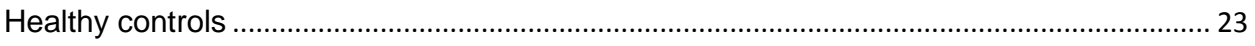

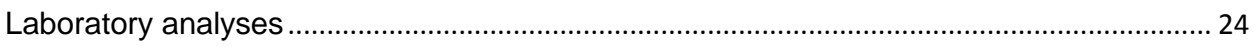

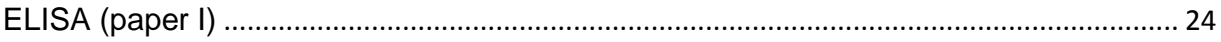

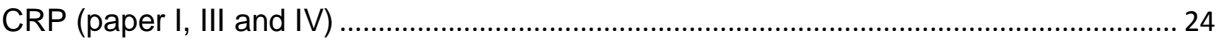

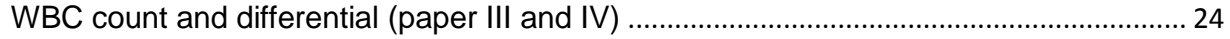

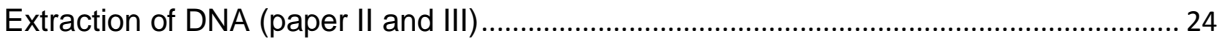

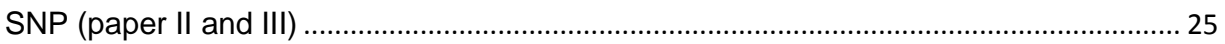

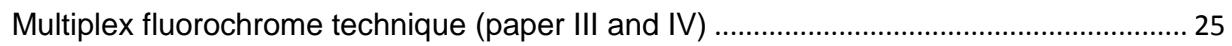

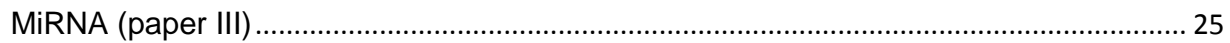

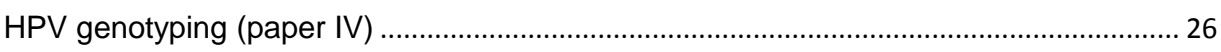

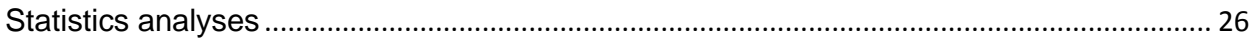

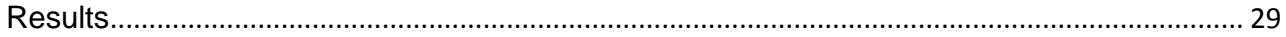




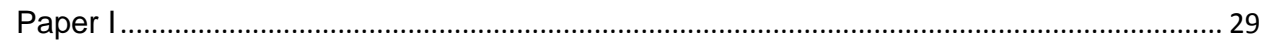

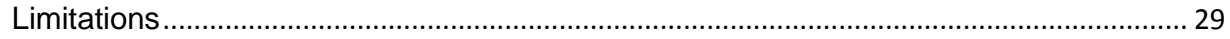

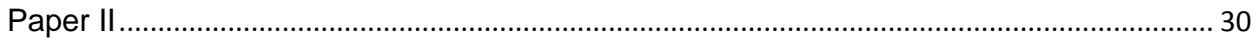

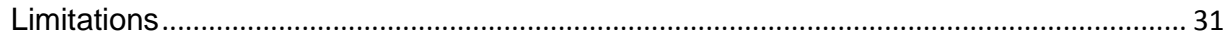

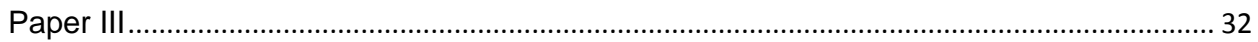

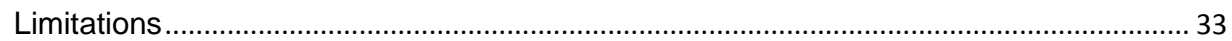

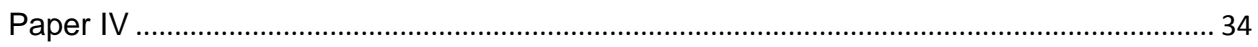

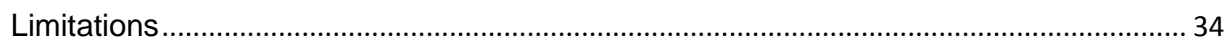

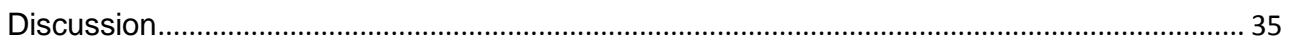

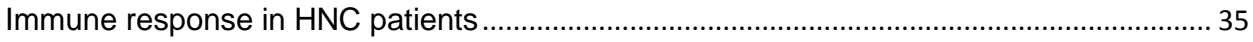

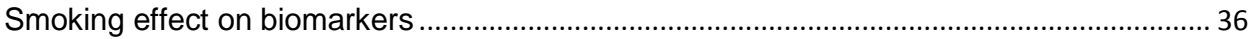

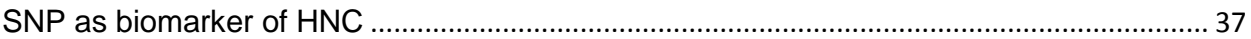

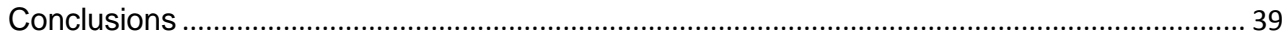

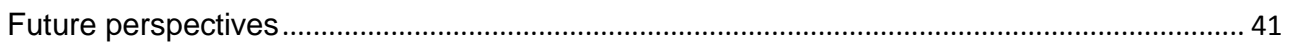

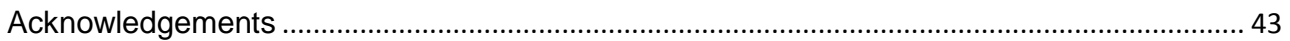

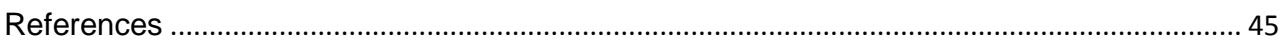




\section{Introduction}

\section{Cancer}

Cancer may occur in any structure or organ in the body. Cancer is characterized by an uncontrolled cell division with a possible spread to surrounding tissues. Renewal of cells is needed due to age or damage, this event occurs in a controlled process. In cancer cells, many of these control mechanisms have been disrupted and an uncontrolled cell division occurs (Hahn and Weinberg, 2002). These cells form a tissue (tumor) with dysfunctional properties. Tumors can be both malignant and benign. Malignant tumors, unlike benign tumors, have the ability to infiltrate adjacent tissues and spread through the blood circulation or lymphatic system to other parts of the body.

The cancer is often named from which organ it originates, e.g. lung, breast or prostate. In addition, it can be classified from the type of tissue or cell it originates and also into solid tumors or cancers in fluids. The most common solid cancers are carcinomas in epithelial cells, that cover the inside and outside of the body.

Cancer is a genetic disease, caused by accumulations of mutations in one cell clone, affecting genes that could stimulate cell growth and cell division (oncogenes), in genes controlling these mechanisms (tumor suppressor genes) or in genes responsible for repairing mistakes in DNA replication (stability genes) (Vogelstein and Kinzler, 2004). Changes in these genes can be inherited or, more often, caused by external environmental factors. Inheritance has an impact on most cancers, but some cancers have higher heritability such as in prostate, colorectal region, breast, melanoma, ovary, and in uterus (Lichtenstein et al., 2000, Mucci et al., 2016). Besides heredity, preventable lifestyle or environmental factors such as UV radiation from sunlight, ionizing radiation from radon, radionuclides in rocks, soils, and building materials, viruses, obesity or via substances such as tobacco and alcohol also have an impact on cancer (Brown et al., 2018, Doll, 1996). It has also been suggested that random DNA replication errors could contribute to mutations that cause cancer (Tomasetti et al., 2017). 


\section{Head and neck cancer}

The diagnose head and neck cancer (HNC) includes solid tumors located in the head and neck area. In Sweden, the tumors are divided in nine diagnose groups (lips, oral cavity, oropharynx, nasopharynx, hypopharynx, larynx, salivary glands, nasal cavity/paranasal sinuses and tumors of unknown primary origin) according to the International Classification of Diseases, $10^{\text {th }}$ edition (Swedish head and neck cancer register, 2018) (Figure 1). Within each group there are subgroups that differ in the way they grow, in the risk of spreading, in forecasting the prognosis and in the treatment. The tumor originates predominantly from squamous cell tissues in the mouth, throat and nasal region (Leemans et al., 2011). The tumors are often aggressive and tissue destructive and are often spread to local lymph nodes (Rivelli et al., 2011). However, HNC rarely metastasize to other part of the body, in comparison to other cancers (Ferlito et al., 2001). Patients have an increased risk of relapses within three years, depending on stage and the tumor locations (Ho et al., 2014). An elevated incidence of a second primary tumor is also seen in HNC patients (Heroiu Cataloiu et al., 2013).

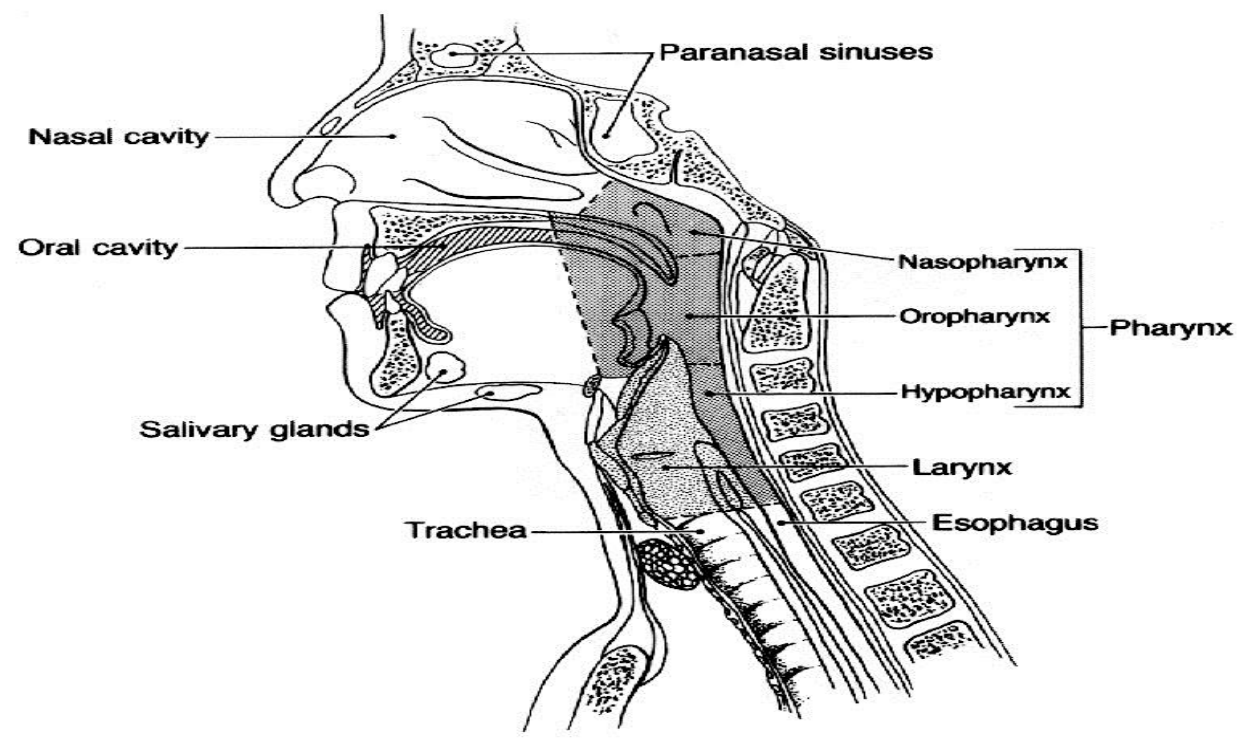

Figure 1. Regions that could be afflicted by head and neck cancer. Reproduced with permission from (Vokes et al., 1993), Copyright Massachusetts Medical Society. 


\section{Epidemiology}

HNC affects more men than women, but can vary between different anatomic locations (Boscolo-Rizzo et al., 2018). Worldwide, HNC accounts, approximately, for 650000 new cases and 330000 deaths annually (Bray et al., 2018). The incidence of HNC is varying globally, mostly dependent on tobacco consumption (Sturgis and Cinciripini, 2007) with differences regarding gender and anatomic subsites (Simard et al., 2014). In countries, where smoking has declined, a decrease in the incident of HNC has been observed and countries with a continued high smoking prevalence, an increase of HNC are expected (Rettig and D'Souza, 2015). In some countries where smoking related HNC have declined, an increased incidence of tumors in oropharynx has been observed and is associated with infections of human papillomavirus (HPV) (Simard et al., 2014). Other factors that might influence the incidence of HNC in specific regions could be betel quid and areca nut consumption in India (Datta et al., 2014) and infection of the oncogenic Epstein-Barr virus (EBV) in populations in Southeast Asia and Southern China (Ngan et al., 2018).

In Sweden during 2016, 1582 individuals were diagnosed with HNC and it corresponds to $2.3 \%$ of all malignant tumors (Swedish head and neck cancer register, 2018). The number of individuals diagnosed with $\mathrm{HNC}$ has increased with $31 \%$ compared to 2008 and is largely caused by the increase in oropharyngeal cancer (Swedish head and neck cancer register, 2018). The median age for the HNC diagnose in Sweden is 65 years for men and 68 years for women and there are differences between anatomic subsites and gender (Swedish head and neck cancer register, 2018). Swedish men have a highest incidence of tumors in larynx, hypopharynx, tumors of unknown primary origin and oropharynx (in descending order) compared to Swedish women (Swedish head and neck cancer register, 2018).

\section{Prognosis}

The survival in HNC is strongly associated with how early the tumor is detected and if the patients develops a tumor recurrence or if the tumor metastasize. More advanced disease at diagnosis is generally associated with poorer survival prognosis (van der Schroeff et al., 2012). The majority of the HNC patients have an advanced disease at diagnosis (Guizard et al., 2017) mostly due to that HNC initially have diffuse symptoms such as sore throat, sinusitis or sores in the mouth and on lips that do not heal. Other factors affecting the survival are tumor location, co-morbidity, surgeon resection margins, treatments, immune suppression or if tumors in oropharynx is infected with HPV (Ang et al., 2010, Eldeeb et al., 2012, Hall et 
al., 2000, Lam et al., 2018, van der Schroeff et al., 2007, van der Schroeff et al., 2012). Life style factors such as smoking or heavy alcohol consumption before and after diagnose also affects the survival (Mayne et al., 2009). The five year relative survival for HNC patients in Sweden has only improved marginally, from $65 \%$ in 2008 to $69 \%$ in 2013 (Swedish head and neck cancer register, 2018).

An important prognostic tool for treatment planning and for the survival of the patients with HNC and all solid tumors is Tumor Node Metastasis (TNM) classification. It classifies the extent of the tumor (T0-4), spread to regional lymph nodes (N0-3) or spread to other locations in the body (M0-M1). The clinical classification (designated TNM or cTNM) is done before any selected treatment. The information could be collected from physical examination, laboratory tests, imaging, endoscopy or biopsy. Within each grading of the tumor, specific subgroups ( $\mathrm{a}, \mathrm{b}$ or $\mathrm{c}$ ) could occur. The TNM ratings of the patients is arranged in numerical stages designated I, II, III or IV with subgroups a, b or c. TNM stages I and II generally indicates moderate disease, while III and IV indicates a more advanced disease. The TNM classification is important for selection of adequate therapy.

The TNM classification may be supplemented with pathological classification (pTNM). The information in the pTNM could be collected from TNM classification, surgery and histological examinations. This could give information on tumor biology, tumor resection margins, possible spread to local lymph nodes or further information on possible distant metastases.

Within the HNC, T, N and M are classified according to guidelines for each diagnosis groups e.g. lip and oral cavity (Table 1a and 1b). Assessments are also made in the eighth edition of TNM classification of Malignant Tumours (Brierley JD, 2017) whether the tumor is positive or negative for high risk HPV (HR-HPV) in the tumor location oropharynx. 
Table 1a. Tumor classification for lip and oral cavity. Modified from TNM classification of Malignant Tumours, 8 th edition.

\begin{tabular}{ll}
\hline T-Primary tumor & Definition \\
\hline & \\
TX & Tumor could not be defined \\
T0 & No tumor is found \\
Tis & Carcinoma in situ \\
T1 & $<2 \mathrm{~cm}$ \\
T2 & $>2<4 \mathrm{~cm}$ \\
T3 & $>4 \mathrm{~cm}$ \\
T4a & (Lip) Tumor invades e.g. bone, nerve, floor of mouth or skin \\
T4a & (Oral cavity) Tumor invades e.g. bone, sinuses or skin of the face \\
T4b & Tumor invades e.g muscles, skull base or carotid artery
\end{tabular}

\section{N-Regional lymph nodes}

$\begin{array}{ll}\text { NX } & \text { Lymph node status could not be defined } \\ \text { N0 } & \text { No regional lymph node metastasis } \\ \text { N1 } & \text { One ipselateral }{ }^{2} \text { lymph node metastasis }<3 \mathrm{~cm} \\ \text { N2a } & \text { One ipselateral lymph node metastasis }>3 \mathrm{~cm}<6 \mathrm{~cm} \\ \text { N2b } & \text { Multiple ipselateral lymph node metastasis }<6 \mathrm{~cm} \\ \text { N2c } & \text { Bilateral }^{3} \text { or contralateral } \\ \text { N3a } & <6 \mathrm{~cm} \\ \text { N3b } & {\text { Metastasis }>6 \mathrm{~cm}^{2} \text { in lymph nodes without extranodal extension }}^{5}\end{array}$

M-Distant metastasis

M0

M1
No distant metastasis

Distant metastasis

${ }^{1}$ No invasive cancer, basal membrane intact. ${ }^{2}$ On the same side of the neck as primary tumor. ${ }^{3}$ On both sides of the neck. ${ }^{4}$ On the opposite side of the neck as the primary tumor. ${ }^{5}$ Tumor invades skin, soft tissue, muscles or nerves. 
Table 1b. Tumor stage classification for lip and oral cavity according to TNM classification of Malignant Tumours, 8th edition.

\begin{tabular}{llll}
\hline TNM Stage & T classification & N classification & M classification \\
\hline \multirow{4}{*}{0} & & & \\
I & Tis & N0 & M0 \\
II & T1 & N0 & M0 \\
III & T2 & N0 & M0 \\
& T3 1, T2, T3 & N0 & M0 \\
IVA & T4a & N0, N1 & M0 \\
& T1, T2, T3, T4 & N2 & M0 \\
IVB & Any T & N3 & M0 \\
& T4b & Any N & M0 \\
IVC & Any T & Any N & M1 \\
& & &
\end{tabular}

\section{Treatment}

Treatment of HNC includes radiotherapy, surgery, chemotherapy, immunotherapy or targeted therapy and is in the majority of cases of curative intent. Surgery and radiotherapy are the dominating options. The choice of treatment depends on the site of the cancer and the TNM stage classification. Tumors classified in stage I and II are generally treated with surgery or radiotherapy, while stage III and IV usually receive a combination of treatment if possible. If the tumor is not resectable, radiation therapy is used in combination with chemotherapy, immunotherapy or targeted therapy. Patients treated with radiotherapy alone or in combination with chemotherapy could experience one or more sideeffects in form of mucositis, nausea, vomiting, diarrhea and anemia (Elting et al., 2008, Groopman and Itri, 1999, Uchiyama et al., 2012). Surgery may lead to cosmetic and functional complications. 


\section{Risk factors for HNC}

The HNC incidence is mainly attributed to tobacco and heavy alcohol consumption especially in combination (Lewin et al., 1998), or HPV infections (Rettig and D'Souza, 2015). Historically, tobacco and alcohol have dominated globally as the cause of HNC, but in the last decades HPV infections has emerged as a major risk factor in the Western countries. The variation in incidence and tumor anatomic location worldwide could be explained by the exposure to different major risk factors.

\section{Smoking}

As a tobacco smoker, there are different tobacco products which could be used and the smoking product pattern differs in regions throughout the world. Products such as shicha are commonly used in Arab countries, kretek in Indonesia, bidis in India and cigars, pipes and cigarettes worldwide. Tobacco smoke can be actively or passively (involuntary exposure to tobacco smoke) inhaled.

Tobacco smoking is major risk factors for several chronic diseases such as cancer, lung diseases and cardiovascular diseases (CVD). Tobacco smoke is estimated to cause seven million deaths per year (World Health Organization, 2017). Smokers lose at least 10 years of life expectancy compared with never smokers (Jha et al., 2013). According to WHO, approximately $35 \%$ men and $6 \%$ women of the worldwide adult population smoked tobacco in 2015 and it is a reduction of $2.8 \%$, compared to 2007, of the total numbers of smokers (World Health Organization, 2017). The WHO report notes that the decrease is mostly associated with smoking cessation in the regions Europe and America. The majority of the 1.1 billion smokers are men in middle- income countries (World Health Organization, 2017). The Public Health Agency of Sweden (Folkhälsomyndigheten, 2019) reported that $7 \%$ (no differences between genders) of the population in Sweden in the age 16 to 84 years was daily smokers in 2018. This is a decrease from $14 \%$ in 2006.

The effect of smoking could be estimated as a financial social cost for health care and loss of production as an employee or at home. The global cost for smoking is estimated as purchasing power parity to $\$ 1852$ billion in 2012 and forty per cent of these costs worldwide, can be attributed to the developing countries (Goodchild et al., 2018). In Sweden, the estimated cost for smoking in 2015 was 31.5 billion SEK. CVD and cancer diagnosis had the greatest costs (7.6 and 7.1 billion respectively) (Andersson et al., 2017). Despite the decreasing number of 
smokers, the cost of smoking in 2015 was higher than in 2001. This could be due to increasing number of diseases found to be associated with smoking (Andersson et al., 2017).

The cigarette smoke contains approximately 5000 chemical substances (Borgerding and Klus, 2005) out of which almost 100 have carcinogenic effect or causes cardiovascular or respiratory diseases (Talhout et al., 2011). During smoking, the tobacco products are heated to at least $880{ }^{\circ} \mathrm{C}$ and this makes the tobacco product more complex in its contents regarding cancerogenic or toxic properties (Hecht and Szabo, 2014). It is estimated that tobacco smoke contains 2800 elements not found in tobacco (Baker, 2006). The hazardous substances of tobacco smoke penetrate the cells, bind to its DNA and have a damaging effect on tumor suppressor genes and oncogenes (Hecht, 2003, Wiencke, 2002). The damage to these genes is usually repaired via the cell DNA repair enzymes (U.S. Department of Health and Human Services, 2010). However, a prolonged and frequent exposure to tobacco smoke can generate permanent effects on tumor suppressor gene TP53, which is commonly mutated in tissues from smoke-related cancers such as lung and HNC (Hecht, 2012, Pfeifer et al., 2002). When the many harmful substances of cigarette smoke gets in contact with the oral cavity and airway epithelial cells, the substances activate the production of pro-inflammatory cytokines (Arnson et al., 2010) that promotes the influx of immune cells such as neutrophils, macrophages, T-lymphocytes (T-cells) and dendritic cells (DCs) (Lee et al., 2012b). The cigarette smoke impairs the immune system with increased risk, severity and duration of infection (Stämpfli and Anderson, 2009). The pro-inflammatory and immune suppressive effect of cigarette smoking could lead to a chronic inflammatory state promoting smoking associated diseases such as CVD, chronic obstructive pulmonary disease and varies types of cancers.

Epigenetic effect of cigarette smoke has also been identified. Altered levels of microRNA (miRNA) caused by smoking are suggested to have an impact on inflammation and immune functions and serves as a mediator of smoking-induced inflammation (Willinger et al., 2017). Cigarette smoke also has an impact on miRNAs which have an effect on tumor suppressor gene or oncogenes and could contribute to smoking induced cancer (Wang et al., 2015).

The risk of a disease caused by smoking declines with years after smoking cessation (Jha et al., 2013). However, the effect of smoking could be seen several years after cessation, with elevated inflammatory activity (Hastie et al., 2008, Van Tiel et al., 2002). Spira et al. reported 
that decreased expression of putative tumor suppressor genes and increased expression of oncogenes were altered in smokers compared to never smokers, despite 20 years after smoking cessation (Spira et al., 2004). The time from cessation to HNC diagnose also have an impact on survival (Cao et al., 2016). Smoking at cancer diagnose is associated with decreased survival among patients with HNC (Sharp et al., 2014). The majority of diagnosed smoking HNC patients quit but a non-insignificant group continue to smoke (Kashigar et al., 2013). Continuously smoking patients treated with radiation, have a higher risk of treatment failure and decreased five year survival compared to patients who had quitted prior to radiotherapy (Chen et al., 2011). Additionally, the patients who continued to smoke had also more complications after surgery with wounds that did not heal and those patients were generally hospitalized for longer time (Hatcher et al., 2016).

\section{Human papillomavirus}

HPVs are double stranded DNA viruses that have tropism for mucosal or cutaneous squamous cell surfaces and are a common cause of benign infections manifested as warts on the skin or in the anogenital region (Ljubojevic and Skerlev, 2014). HPV is also a human carcinogen, causing HNC and penile, vulvar, cervix and anal cancer (Parkin and Bray, 2006). HPV are classified in high risk human papillomavirus (HR-HPV) or low risk human papillomavirus genotypes dependent on malignant progression ability (de Villiers et al., 2004) and the most frequent HR-HPV genotypes are 16 followed by 18. Since the beginning of the 1980s, HPV has been identified as a risk factor for HNC (Syrjanen et al., 1983). HPV infections associated with HNC cancer have increased the last decade (Chaturvedi, 2012) and the highest prevalence of HPV infections are in tumors in oropharynx (Kreimer et al., 2005). The patients with HPV associated HNC are often younger without smoking or heavy alcohol consumption habits. It has been reported that $49 \%$ of the tumors located in tonsils and $40 \%$ in tongue base are infected (Hammarstedt et al., 2006, Dahlgren et al., 2004). Patients with HPV positive oropharyngeal HNC have better prognosis compared to negative (O'Rorke et al., 2012). However, the survival benefits for patients with HPV positive tumors diminish if the patients have a smoking history (Ang et al., 2010).

In HR-HPV, E6 and E7 proteins are essential for malign transformation. The proteins degrade and inactivate the tumor suppressor proteins p53 and pRB leading to interference in pathways regulating cell proliferation, apoptosis and DNA repair, processes that are important to eliminate malfunctioning cells (Sano and Oridate, 2016). Almost every HR-HPV infection 
spontaneously clears within one to two years (Insinga et al., 2010), but persistent infection occurs in about $2 \%$ of the population infected (Frazer et al., 2011). These HPV infections are more frequent in immunosuppressive conditions (Berkhout et al., 2000, Koshiol et al., 2006). Persistent HPV infections may also be associated with chronic inflammation as a higher incidence of oropharyngeal HPV positive tumors has been reported from patients with chronic inflammatory disease in the oral cavity (Tezal et al., 2012).

\section{Other risk factors for HNC}

Excessive alcohol use is associated with HNC, particularly in hypopharynx. Alcohol is an independent risk factor for HNC for individuals who had never smoked (Freedman et al., 2007), but it also have a major synergistic effects with smoking (Anantharaman et al., 2011).

Snus is a commonly used smokeless tobacco product in Sweden. Swedish snus consumption seems not to be associated to HNC (Lewin et al., 1998, Schildt et al., 1998). However, a higher risk of $\mathrm{HNC}$ in the oral cavity has been found in users of American chewing tobacco and snuff, compared to non-users (Wyss et al., 2016). Different amount of carcinogenic tobacco-specific nitrosamines (Kumar et al., 2018) in the Swedish and American products might be an explanation of the different association to HNC.

Nasopharyngeal carcinoma type of $\mathrm{HNC}$ is a relatively rare malignancy in Sweden but is more common in the Southeast Asia and Southern China. This higher incidence are suggested to EBV infections, with genetic and environmental factors, contributing to the development of nasopharyngeal carcinoma in these populations (Chua et al., 2016). It has also been reported that smoking is associated with the activation of an EBV infection (Xu et al., 2012).

Betel quid chewing is of widespread use in South and South-East Asia. The contents vary among users but could contain betel leaf, areca nut and slaked lime (IARC Working Group on the Evaluation of Carcinogenic Risks to Humans, 2004). There is an higher risk for HNC and particularly in the oral cavity for betel quid chewers (Lee et al., 2012a) .

Furthermore, UV-light exposure (Perea-Milla Lopez et al., 2003), poor oral health (Rosenquist et al., 2005), immune suppression (Adami et al., 2003) or occupational exposure to toxins (Becher et al., 2005), has been associated with HNC. 


\section{Immune systems and cancer}

The immune system is composed of two main systems, the innate and adaptive, both with anti-tumor properties (Warrington et al., 2011). The immune system distinguishes self from non-self and may distinguish normal cells from mutated cells such as cancer cells (Mapara and Sykes, 2004, Van Parijs and Abbas, 1998).

The innate immune system is categorized by a rapid and nonspecific response while the adaptive immune response is more immunologically specific and durable and is dependent on antigen-presenting cells (APCs) (Warrington et al., 2011).

The first line of defense against pathogens or abnormal cells is the innate immune system. It consist of cells such as macrophages, neutrophils, DCs, mast cells, basophils, eosinophils, and natural killer (NK) cells (Warrington et al., 2011). The primary effector cells in the innate immune system are the NK cells (Vivier et al., 2011) which are capable of eliminating tumor cells by recognition of the tumors as non-self (Campbell and Purdy, 2011).

T-cells in the adaptive immune system are activated by the recognition of antigens presented by APCs such as macrophages or DCs (Warrington et al., 2011). This process initiates a differential of T-cells into subpopulations such as T-helper cells, T-regulatory (T-reg) cells or the effector cells cytotoxic T-cells (Ruffell et al., 2010). Some T-cells differentiate into longlived memory T-cells (Masopust and Schenkel, 2013). A second major cell type in the adaptive immune system is the B-lymphocytes. They are responsible for antibody production and have a role in the initiation of T-cell immune response (LeBien and Tedder, 2008).

\section{Tumor microenvironment}

The non-malignant cells within solid tumor microenvironment (TME) could be immune cells, fibroblasts, tumor vasculature associated cells and lymphatics cells and the interactions between these cells and the malignant cells have an impact on TME (Chen et al., 2015).

The immune systems have antitumor properties. However, the tumor may modify the immune response and induce a chronic inflammatory environment with tumor promoting function (Mantovani et al., 2008, Grivennikov et al., 2010). The recruitment of different subset of immune suppressing cells into TME is regulated by chemokines expressed by tumor, immune or stromal cells (Nagarsheth et al., 2017). The composition of immune cell populations in TME differs between cancer patients and types of tumors, regarding tumor suppressive or 
tumor promoting properties. Cytotoxic CD8+ T-cells, DCs, NK cells and M1 type macrophages are generally considered to have anti-tumor activity, and cells that generally are considered to promote tumor growth and development are T-reg cells, myeloid-derived suppressor cells (MDSC), immature DCs, or M2 type macrophages (Gabrilovich and Nagaraj, 2009, Gajewski et al., 2013, Poh and Ernst, 2018, Ruffell et al., 2010, Shiao et al., 2011). In general, high levels of T-reg cells are regarded as a negative prognostic marker in most cancer types (Shang et al., 2015, Hiraoka et al., 2006, Petersen et al., 2006).

Tumor mutation burden (TMB) may be high, with an increased number of neoantigens that could be recognized by the immune system leading to the recruitment of tumor-infiltrating lymphocytes (Chan et al., 2019). T-cells and NK cells are recruited by chemokines and proinflammatory cytokines secreted by cells in the TME (Melero et al., 2014), and marks an immunologic activity against tumor cells. The degree of inflammation in the tumor is associated with the level of infiltrated immune cells (Masucci et al., 2016).

\section{Immune response in $\mathrm{HNC}$}

HNC is generally considered as an immune suppressive type of cancer (Duray et al., 2010, Rothschild et al., 2018). HNC have a high TMB compared to tumors from other anatomic locations (Chalmers et al., 2017). The anti-tumor activity of the infiltrated cells in the TME is however impaired by suppressing cytokines, T-reg cells or MDSCs (Ferris, 2015). The HNC cells may also downregulate its surface antigen expressions to avoid identification and elimination by T-cells (Russell et al., 2013). The activating receptors on NK cells are downregulated in HNC patients and inhibitory receptors are overexpressed (Korrer and Kim, 2017).

Increased levels of T-reg cells are seen in the TME of HNC patients (Lechner et al., 2017) and in the circulation (Chikamatsu et al., 2007). The data on the influence of T-reg cells on HNC are inconclusive. Decreased survival is associated with tumor infiltrating T-reg cells (Liang et al., 2011), and the elevated T-reg cell levels corresponds to poorly differentiated tumors (AlQahtani et al., 2011). In contrast, better survival and lower local region spread has been shown to be associated with elevated levels of infiltrating T-reg cells (Zhang et al., 2010, Badoual et al., 2006).

Decreased levels of absolute numbers of lymphocytes in HNC patients, compared to healthy individuals is reported, and that low levels of T-cells among the patients were associated with 
recurrence of disease and second primary tumor (Kuss et al., 2004). An inhibition of T-cell activation also corresponds to elevated levels of circulating MDSC in HNC patients (Chikamatsu et al., 2012).

The systemic inflammation in HNC patients is reflected by the increased number of circulating monocytes, neutrophils and total leukocytes in comparison to healthy individuals (Millrud et al., 2012). The elevated levels of monocytes and neutrophils are suggested to be immature cell populations (Millrud et al., 2012). The neutrophils are suggested to have an immune suppressive function (Coffelt et al., 2016). However, a subpopulation of neutrophils could also have anti-tumor properties (Fridlender and Albelda, 2012). A marker for systemic inflammatory response to cancer, is also the neutrophils to lymphocyte ratio (NLR) (Zahorec, 2001). An elevated NLR in HNC patients prior to treatment is linked to recurrence and decreased overall survival (Bobdey et al., 2017, Rassouli et al., 2015).

\section{Biomarkers}

A biomarker is defined according to the National Cancer Institute, USA, as "a biological molecule found in blood, other body fluids, or tissues and is a sign of a normal or abnormal process or of a condition or disease". Biomarkers could include cells, proteins, nucleic acids, antibodies, peptides, gene expressions, SNPs and miRNAs. The biomarkers could be collected from whole blood, serum, plasma, stool, urine, saliva or from tissues biopsies. Prognostic biomarkers may indicate a disease, disease progression, recurrence or survival. Predictive biomarkers could indicate the likelihood to response to a selected therapy.

It is important that the biomarkers are useful in clinical decisions. For guidance in how the biomarker should be used a thorough validation is required (Henry and Hayes, 2012). The biomarker should also be cost effective as medical costs continue to increase (Scott, 2010).

\section{MiRNA}

MiRNAs are short, approximately 19 to 25 nucleotides, endogenous non-coding RNA molecules. They could target a large number of complementary or partial complementary regions of one or more mRNA (Bartel, 2009). The interaction between miRNA and mRNA promotes degradation or inhibition of the mRNA transcript (Oliveto et al., 2017). MiRNAs are suggested to negatively regulate a large number of genes such as genes involved in cellproliferation, differentiation or apoptosis, and tumor suppression (Oliveto et al., 2017). Most of the miRNA are intracellular but small amounts could be extracellular such as in plasma, 
urine, tears, saliva, seminal fluid or cerebrospinal fluid (Ghai and Wang, 2016). Some 2300 different miRNAs has been found in humans (Alles et al., 2019).

In tumorigenesis, a miRNA could have oncogenic properties (oncomir) by the repression of tumor suppressor genes and thereby promoting tumorigenesis. On the contrary, a miRNA could repress the expression of oncogenes, obstructing the tumorigenesis process and thus acting as a tumor suppressor miRNA (Oliveto et al., 2017). Generally, oncomirs are overexpressed and tumor suppressive miRNAs are underexpressed, in most cancers (Svoronos et al., 2016). As one single miRNA could regulate various different genes in different pathways, the oncogenic or tumor suppressive effects is dependent on which type of cell or cancer that is affected by the miRNA (Sun et al., 2013).

In HNC, dysregulation of miRNAs indicates a risk for metastasis and recurrence, poor survival, and is a potential biomarker for HNC (Scapoli et al., 2010, Ganci et al., 2016, Liu et al., 2010). MiRNAs could also affect the efficiency of chemo and radiation therapy (Bourguignon et al., 2012, Li et al., 2013).

\section{SNP}

Single nucleotide polymorphism (SNP) is the most common inherited variation in the three billion-bases of the human genome, representing differences in one nucleotide at a specific genomic sequence site. The definition of a SNP is that the differences at one position in the genome have a frequency of $1 \%$ or more in a population (Brookes, 1999). SNPs are estimated to be found once in every 1000 nucleotides (Wheeler et al., 2008). The SNPs could be homozygotic or heterozygotic, depending on the prevalence in the parents. The frequency of various SNPs is different among ethnic populations (Guthery et al., 2007).

Out of the millions of SNPs in the human genome, the majority is located in non-coding regions and the rest in coding regions. SNPs in coding regions could change the amino acid sequence and affect protein stability and mRNA expression levels (Aldasoro Arguinano et al., 2017, Witham et al., 2011). Most of the SNPs in the human genome are of little or no importance. However, they could play a role in the diversity among individuals or be involved in the development of human diseases.

An increased or decreased risk of HNC is associated with SNPs in genes related to tumor suppression, metabolic pathways, HLA complex and DNA repair (Wu et al., 2017, Saeed et al., 2017, Tsai et al., 2002). Nogeira et al. found a SNP in DNA repair genes correlating to 
response to combined chemo and radio therapy in HNC patients (Nogueira et al., 2018). A decreased survival of HNC patients, with SNP in genes associated with cell growth and cell division, has been shown (Pasqualetti et al., 2015) and a risk for recurrence correlates with SNP in a cell cycle regulating gene (Matthias et al., 2006).

\section{Cytokines, chemokines and proteins}

An inflammation could both have antitumor or pro-tumor activity, depending on the immune cell phenotypes in the TME. The phenotypes are due to the secreting signaling molecules such as cytokines, chemokines, and proteins released in the TME.

Cytokines are small cell-signaling proteins that influence cellular functions with interactions and communications between cells and their receptors. Cytokines are regulating or controlling and determine the fate of immune cell growth, differentiation and activation (Borish and Steinke, 2003). They are produced by various cell populations, but mainly by T-cells and macrophages (Zhang and An, 2007). The cytokine profile could reflect the tumor-associated immune response, indicating presence or absence of functional immune response in the TME (Burkholder et al., 2014). However, cytokines may be pleiotropic. The cytokines interferon gamma (IFN- $\gamma$ ) and tumor necrosis factor alpha (TNF- $\alpha$ ) could have both anti-tumor and tumor enhancing properties (Mojic et al., 2017, Wang and Lin, 2008).

Increased levels of the cytokines interleukin (IL)-4, IL-6 IL-10, transforming growth factor beta, and decreased levels of IFN- $\gamma$ in serum and increased levels of IL-4 and IL-10 with decreased levels of IL-12 in peripheral blood mononuclear cells of HNC patients compared with healthy individuals have been reported (Bose et al., 2008, Gaur et al., 2014, Lathers et al., 2003). These findings indicate an impaired antitumor response of HNC patients. However, the antitumor response reflected by the cytokines may be altered during HNC progression (Maggioni et al., 2017). Also, an increased level of IFN- $\gamma$ has been associated with tumor regional spread (Bussu et al., 2018). An elevated level of IL-6 in serum from HNC patients is correlated with higher rate of recurrence and poor survival (Duffy et al., 2008, Chang et al., 2013).

Chemokines are a group of chemotactic cytokines that recruits leukocytes and controls the migration of the leukocyte to the site of inflammation (Sokol and Luster, 2015). They also have functions in the development, differentiation and homeostasis of immune cells (Griffith et al., 2014). Chemokines could recruit effector immune cells such as T-cells and NK cells to 
the TME as an antitumor response (Nagarsheth et al., 2017). Conversely, they could also contribute to immune suppression, promoting tumor progression and metastasis by recruiting tumor suppressor cells like T-reg cells and MDSC (Nagarsheth et al., 2017).

The monocyte chemoattractant protein 1 (MCP-1) is implicated as a chemokine with tumor promoting properties in $\mathrm{HNC}$ by its recruitment of carcinoma associated fibroblasts that stimulate tumor growth and tumor migration (Li et al., 2014, Ferreira et al., 2008). Rentoft et al. found that HNC patients with high levels of CXCL10 in the tumors, had a poor radiotherapy response and decreased survival (Rentoft et al., 2014).

Circulating inflammatory proteins levels are changed during acute and chronic inflammation. These proteins are released as an inflammatory response to chemicals or to cellular injuries. C-reactive protein (CRP) is an acute phase protein produced primarily in the liver by hepatocytes after stimulation from IL-6 (Depraetere et al., 1991). CRP is a part of the innate immune system activating the complement system which generate pro-inflammatory cytokines that enhance the inflammatory response (Du Clos, 2000). CRP has also been associated with the differentiation of naïve T-cells towards a tumor suppressing cell population (Zhang et al., 2015). An increased circulating level of CRP has traditionally been used as a marker of infection and inflammation with a cut off levels of $10 \mathrm{mg} / \mathrm{L}$.

A chronic low-grade inflammation could also be reflected by moderately elevated levels of CRP and is associated with an increased risk for various cancers (Heikkila et al., 2007, Allin et al., 2009). In HNC, moderately elevated levels of CRP in patients prior to treatment were associated with decreased survival, independent from other factors such as smoking history or age and a higher risk of distant metastases (Katano et al., 2017). Chen et al. reported that HNC patients with CRP levels above $10 \mathrm{mg} / \mathrm{L}$ before and also after treatment had decreased survival (Chen et al., 2019). In the same study they also concluded that TNM stage was associated with the levels of CRP, with higher levels of CRP in patients diagnosed in stage III and IV compared to stage I and II. Patients with moderately elevated CRP levels also have a higher risk for local spread to regional lymph nodes (Acharya et al., 2018). The results concerning prognosis and elevated levels of CRP are not all conclusive, as Kruse et al. found no differences, in patients prior to surgery, regarding CRP levels and recurrence or metastases (Kruse et al., 2010). Since different levels of CRP have been used for stratification of patients, there is no consensus regarding "high, low or elevated" CRP levels of HNC 
patients. However, a raised value seems to be associated with poorer prognosis (Andersson et al., 2014). 


\section{General aims}

The overall aim was to find biomarkers that are associated with HNC and the influence of cigarette smoke on the levels of the biomarkers. The biomarkers should be blood based, easily and rapidly analysed in routine laboratory at low cost.

The specific aims were to:

- To investigate the role of some plasma inflammatory or immune regulatory cytokines and CRP as biomarkers for survival of HNC patients (Paper I).

- To disclose the impact of variations in genes associated to cell cycle progression, cell death, DNA repair and immune response on cancer risk, tumor recurrence and survival of HNC patients (Paper II).

- To investigate the smoking impact on circulating levels of white blood cells (WBCs), CRP, cytokines, chemokines, proteins and miRNAs in healthy individuals. The influence of SNPs on inflammatory cytokine and protein levels, were also analysed (Paper III).

- To evaluate the separate effects of smoking and HNC on circulating inflammatory or immune regulatory biomarkers and the impact of HR-HPV, age and gender on the biomarkers (Paper IV). 


\section{Materials and Methods}

\section{Patients}

In paper I and IV, patients were all histologically confirmed as head and neck squamous cell carcinoma (HNSCC), wheras in paper II, the diagnose HNC was used. The follow-up time was at least 36 months in paper I and II. Thirty six months follow-up were not available on the patients in paper IV. The treatment of patients consisted of surgery and/or radiotherapy, and for some patients chemo therapy and Erbitux (epidermal growth factor receptor inhibitor) was added. Samples were collected at the time of diagnosis and before any treatment. TNM classifications were done according to the International Union Against Cancer (UICC) TNM Classification of Malignant Tumours. Clinical data such as age, sex, tumor site, recurrence, metastasis, date of diagnosis, TNM stage, treatment, mortality and tumor HR-HPV status (paper IV), were collected from the patient's medical records. In case of no information on tumor HR-HPV status for patients included in paper IV, supplementary analysis was done. No data on smoking status for patients in paper I and II was available, while smoking status were recorded in paper IV.

The patients in paper I $(\mathrm{n}=100)$ were diagnosed, treated and included from Department of Otolaryngology and Department of Oncology, Karolinska University Hospital, Stockholm during 2000 through 2005.

In paper II, the 100 patients in paper I were included. Besides, $74 \mathrm{HNC}$ patients from Department of Otorhinolaryngology, Uppsala University Hospital, Uppsala $(n=28)$, Department of Otorhinolaryngology, Linköping University Hospital, Linköping ( $\mathrm{n=5}$ ) and from Department of Oncology, Ryhov County Hospital, Jönköping ( $n=41)$. All patients were of Caucasian origin and were recruited during 2000 through 2013.

In paper IV, all patients ( $\mathrm{n}=87$ ) were included during 2012 through 2017 from Department of Oncology, Ryhov County Hospital, Jönköping. They were 51 non-smoking and 36 smoking HNSCC patients. The smoking patients $(n=36)$ were 34 current smokers at diagnosis and two had stopped smoking within four years prior to diagnosis. The non-smoking patients were never smokers and three previous smokers (stopped smoking 8, 30 and 35 years before diagnosis, respectively). 
All patients included in the studies are presented in Table 2 with age, gender, tumor site and clinical TNM stage.

Table 2. Age, gender, tumor site and clinical TNM stage of patients included in Paper I, II and IV.

\begin{tabular}{lccc}
\hline Parameter & Paper I & Paper II & Paper IV \\
\hline Patients & $\mathrm{n}=100$ & $\mathrm{n}=174$ & $\mathrm{n}=87$ \\
Median age, years & 62 & 62 & 64 \\
& & & \\
Gender & 73 & 127 & 70 \\
Male & 27 & 47 & 17 \\
Female & & & \\
& & & \\
Tumor site & 28 & 50 & 23 \\
Oral cavity & 35 & 84 & 31 \\
Oropharynx & 7 & 19 & 6 \\
Hypopharynx & 6 & & 4 \\
Salivary glands & 5 & & 19 \\
Cancer Unknown Primary & 19 & 21 & 4 \\
Larynx & & & \\
Nasopharynx & & & \\
Clinical TNM stage & 37 & 41 & 62 \\
I+II & 63 & & \\
III+IV & & & \\
& & & \\
\hline
\end{tabular}




\section{Healthy controls}

In paper I, 48 healthy blood donors were included as controls, during 2000 through 2005 from Uppsala University Hospital, Uppsala. They were five females and 43 males, with a median age of 55 years. Fourteen of the controls were previous smokers with no information regarding time for cessation.

In paper II, 245 healthy blood donors were included (122 females and 123 males, median age 55 years). Forty six were from paper I. Besides, blood donors from Ryhov County Hospital, Jönköping ( $\mathrm{n}=148,104$ non-smokers, 16 smokers and 26 previous smokers) and from Karolinska University Hospital, Stockholm $(n=51)$ were recruited. No information about smoking habits of the controls from Uppsala University Hospital, Uppsala and from Karolinska University Hospital, Stockholm was available.

In paper III and IV, a total of 140 controls were included. They were 39 current cigarette smokers (9 males and 30 females, median age 61 years) without any use of other tobacco products. Nine individuals were recruited by advertisement in a local radio station, 10 blood donors were recruited at Ryhov County Hospital, Jönköping and 20 were recruited from the Department of Periodontology, Jönköping. The samples from Department of Periodontology, Jönköping were drawn three months after odontological treatment and the individuals showed no clinical signs of local inflammation. The smokers estimated their daily cigarette consumption from 1 to 30 cigarettes (mean: 11 cigarettes) and had a smoking history ranging from 7 to 56 years (median: 40 years). The non-smokers were 101 healthy blood donors (37 males and 64 females, median age 54 years).

None of the healthy controls included in the four papers, had a history of malignant or autoimmune disease or received any treatment with immune-modulating agents prior to blood samples collections. 


\section{Laboratory analyses}

ELISA (paper I)

The levels of plasma cytokines, IL-2, IL-6, granulocyte-macrophage colony-stimulating factor (GM-CSF) and TNF- $\alpha$ were analysed by Enzyme-linked immunosorbent assay (ELISA) (Invitrogen Corporation, Carlsbad CA) according to the recommendations of the manufacturer. The plasma was separated within three hours and stored at $-80{ }^{\circ} \mathrm{C}$ until analysed. The product absorbance of patient and control samples was collected by Spectrophotometer, Sunrise (Tecan, Salzburg, Austria). A seven point standard curve included in the assay was used to quantify the cytokine levels.

CRP (paper I, III and IV)

Plasma high-sensitivity CRP levels were analysed in the range of $0.16 \mathrm{mg} / \mathrm{L}$ to $10 \mathrm{mg} / \mathrm{L}$ using Siemens Advia 1800 (Siemens Healthcare, Erlangen, Germany) with reagents from the same company. After two repeated higher levels than $10 \mathrm{mg} / \mathrm{L}$, a CRP analyse with a range of 4 to $300 \mathrm{mg} / \mathrm{L}$ was done using the same instrument with reagents from the same company. The plasma samples were stored at $-80{ }^{\circ} \mathrm{C}$ until analyse.

\section{WBC count and differential (paper III and IV)}

A WBC count and differential, including levels of total WBC, neutrophils, monocytes, lymphocytes, basophils and eosinophils was done by automated haematology analyser Sysmex XE-2100 and Sysmex XE-5000 (Sysmex Corporation, Kobe, Japan). The analyses were done within four hours after blood sample collections in EDTA tubes.

\section{Extraction of DNA (paper II and III)}

The extraction of DNA, used as template, for the SNP analysis was done from EDTA blood using BioRobot M48 with MagAttract DNA Blood kit (QIAGEN, Hilden, Germany). The quantity and quality of the DNA was analysed by Spectrophotometer Nanodrop ND-1000 (Thermo Fisher Scientific, DE). 


\section{SNP (paper II and III)}

Genotyping of the SNPs was done by the Illumina Golden Gate assay according to the manufacturer's protocol at the SNP\&SEQ Technology Platform, Uppsala University (Steemers et al., 2006). This platform enables multiplex analysis of all 45 SNP genotypes included in paper II. Reagents from Applied Biosystems (Foster City, CA) and analyses on Bio-Rad CFX96 instrument (Bio-Rad, Hercules, CA) was also used for the five SNPs in paper III. All SNPs were tested and passed the two hits in the dbSNP database or Hap Mapvalidated SNPs and were tested for the Hardy-Weinberg equilibrium.

\section{Multiplex fluorochrome technique (paper III and IV)}

Levels of plasma IL-2, IL6, IL-10, IL-12p70, MCP-1, Rantes, IFN- $\gamma$, TNF- $\alpha$, macrophage inflammatory protein 1 beta (MIP-1 $\beta$ ) and platelet-derived growth factor-BB (PDGF-BB) were analysed with custom made 10-plex kit (Bio-Rad Laboratories, Hercules, CA) using multiplex fluorochrome technique, (Luminex $\mathrm{xMAP}^{\mathrm{TM}}$ Technology, Austin, TX). The fluorescence intensities were collected using Bio-Plex 200 system, Bio-Plex Manager Software 5.0 (Luminex xMAP Technology). Premixed lyophilized standards provided in the kits were used to generate a 9-standard concentration set (with a 4-fold dilution) and the diluent was used as a blank. Concentrations of each cytokine were calculated using a logistic fit curve from the standard curve. As minimum, a threshold of 50 microspheres per region was set.

\section{MiRNA (paper III)}

Before the extraction of plasma miRNA, the samples were checked for lipid and heamaglobulin contents using Spectrophotometer Nanodrop ND-1000 (Thermo Fisher Scientific). Samples with high levels of lipid and heamaglobulin contents were excluded. Total RNA (included miRNA) was then extracted from plasma using miRCURY biofluids kit (Exiqon, Vedbaek, Denmark) according to the manufacturer.

After the extraction, cDNA synthesis was done using miRCURY LNA ${ }^{\mathrm{TM}}$ Universal microRNA PCR, Universal cDNA Kit II (Exiqon, Vedbaek, Denmark). Expression levels of 11 miRNA (let-7a-5p, miR-15b-5p, miR-21-5p, miR-25-3p, miR-30-5p, miR-101-3p, miR103a-3p, miR-126-3p, miR-145-5p, miR-191-5p, miR-451a) were analysed on Bio-Rad CFX96 instrument (Bio-Rad, Hercules, CA) using miRCURY LNA ${ }^{\mathrm{TM}}$ Universal microRNA PCR, Exilent SYBR ${ }^{\circledR}$ Green master mix and LNA PCR primer sets (Exiqon, Vedbaek, Denmark) with a $\mathrm{Ct}>37$ as a cut-off level. 
RNA spike-in UniSp2, 4 and 6 (RNA Spike-in kit UniRT, Exiqon, Denmark) were used for monitoring extraction, cDNA synthesis and qPCR efficiency and samples with a $\mathrm{Ct}$ value \pm 1 were re-extracted and re-analysed. miR-23a-3p was selected as stable reference gene for normalization using GeNorm algoritms (MultiD Analyses, Göteborg, Sweden) of the analysed miRNA levels. The normalized value $\mathrm{Ct}$ was computed: $\mathrm{Ct}=\mathrm{Ct}$ ref $\Delta \mathrm{Ct}$ sample.

\section{HPV genotyping (paper IV)}

The presence of HR-HPV genotypes in formalin-fixed paraffin-embedded (FFPE) tumor tissues was analysed using PCR, at Department of Pathology, Linköping University Hospital, Linköping with extraction kit QIAamp DNA FFPE Tissue kit (Qiagen, Hilden, Germany) and INNO-LiPA HPVgenotyping Extra II (Fujirebio,Ghent, Belgium). FFPE tumors tissues were also analysed with Roche cobas 4800 HPV real-time PCR-based system (Roche Molecular Diagnostics, Branchburg, NJ) at Department of Laboratory Medicine, Ryhov County Hospital according to (Kerr et al., 2016). The HR-HPV genotypes detected by PCR based assays were $16,18,31,33,35,39,45,51,52,56,58,59,66$ and 68. Additionally, immunohistochemical staining for p16 as a surrogate marker for HR-HPV was analysed at Department of Pathology, Ryhov County Hospital, Jönköping.

\section{Statistics analyses}

Spearman's rank correlation was used in paper I and III for the cytokines and CRP levels in correlation with tumor stages or tumor location and for the association between IFN- $\gamma$ and miR-21 levels, respectively. Student's $t$ test was used in paper I to evaluate differences in plasma cytokine and CRP levels between patients and controls. Fisher's exact test and odds ratios with $95 \% \mathrm{CI}$ were calculated for survival in correlation to CRP and TNF- $\alpha$ levels, in paper I and for analyses of SNP differences between patients and controls groups in paper II. Cox regression was used for patient survival according to TNM stage in combination with TNF- $\alpha$ and CRP levels in paper I. Kaplan-Meier analysis was done with a log-rank test to evaluate differences between patients survival, stratified on SNP genotypes, in paper II. A linear regression model adjusting for age and gender was used in paper IV to compare the levels of cytokines, chemokines, CRP, WBCs and miRNAs between smokers and nonsmokers. To adopt the effect of smoking, a likelihood ratio test was used. Mann-Whitney U test was used to compare SNP genotypes related to smoking status and levels of inflammatory cytokines, chemokines or protein in paper III and to evaluate differences in levels of the biomarkers induced by HNC and/or smoking, comparing patients and controls in paper IV. 
Kruskal-Wallis test with Dunn's test were used when comparing the smoking and nonsmoking groups of patients and controls in paper IV. A multivariable linear regression model was used to predict the impact of smoking, HNC, gender, age and tumor HR-HPV infection on the levels of the biomarkers in paper IV.

In all studies a $p$ value $\leq 0.05$ was considered statistically significant. 


\section{Results}

\section{Paper I}

The objective of this study was to investigate a possible role of plasma cytokines (IL-2, IL-6, GM-CSF, TNF- $\alpha$ ) or protein (CRP) associated with immune response or inflammation as biomarkers for survival of HNC patients.

There was a statistically significant difference between the mean values of CRP and TNF- $\alpha$ levels in patients plasma (7.94 mg/L and $26.51 \mathrm{pg} / \mathrm{mL}$, respectively) compared with the levels in the plasma of the controls $(1.8 \mathrm{mg} / \mathrm{L}$ and $20.12 \mathrm{pg} / \mathrm{mL}$, respectively). No differences were found when comparing plasma levels of IL-2, IL-6 and GM-CSF. The higher CRP and TNF- $\alpha$ levels found in the patients were independent of TNM stage or tumor location.

During the 36 month follow-up of the 100 patients included, 57 survived and 43 died. Sixty eight per cent of the patients diagnosed in stage I and II survived, while $51 \%$ of the patients diagnosed in stage III and IV survived. There was a statistically significantly higher survival rate among the patients with lower than mean levels of CRP and a trend to higher survival of patients with lower than mean levels of TNF- $\alpha(p=0.07)$.

By combining the levels of CRP and TNF- $\alpha$ above or under mean levels, with TNM stage, four groups were designated, a) patients in stage I+II with high levels of both CRP and TNF$\alpha, b)$ patients in stage III+IV with high levels of both CRP and TNF- $\alpha, c)$ patients in stage I+II with low levels in either or both of the biomarkers and d) patients in stage III+IV with low levels in either or both of the biomarkers.

During 36 months follow-up, patients in group b had a statistically significantly lower survival rate $(25 \%)$ than patients in group $\mathrm{d}(60 \%)$. The patients in group a, had a lower survival rate $(50 \%)$ than patients in group c (72\%), although not statistically significant.

\section{Limitations}

As tumor HR-HPV infections influence survival in HNC patients, the lack of information on HR-HPV status was a limitation. Information on smoking status of the patients and controls were also missing. However, no influence of HR-HPV status was detected in paper IV and the study revealed that smoking had no major impact on the levels of CRP and TNF- $\alpha$. 
Due to the collection of blood in heparinized tubes, the multiplex fluorochrome technique for quantification of cytokine levels was not possible, but ELISA technique was used. Thus, a comparison with results in paper III and IV where multiplex fluorochrome technique were used, was not possible. However, the correlation between these assays is high (dupont et al., 2005).

\section{Paper II}

The objective of this study was to investigate the influence of 45 SNPs located in 41 genes associated with cell cycle progression, cell death, DNA repair, and/or immune response on cancer risk, tumor recurrence and survival of HNC patients. Fifty seven patients died and 59 patients were observed with recurrence during the 36 months of follow-up.

Thirteen SNPs in 11 genes CCL4, CCL5, IFN- $\gamma, I L 12 R B 2, T N F-\alpha, M T H F R, E G F, P R K D C$, Rad 52, Caspase 8 and Perforin were related to an increased cancer risk when comparing SNP frequency among patient and controls (Table 3).

Five SNPs in four immune response genes (CCL5, IL-2, TNF- $\alpha$ and Perforin) were associated with tumor recurrence when comparing SNP genotypes among the patients (Table 3).

Two out of the 45 candidate SNPs were associated with patient survival time. These were located in two immune response genes, IL12RB2 and TNF- $\alpha$ (Table 3). 
Table 3. SNPs that with statistical significance indicate risk of HNC, risk of recurrence or risk of reduced survival. SNP gene location and gene function is indicated.

\begin{tabular}{|c|c|c|c|c|c|}
\hline \multirow[b]{2}{*}{ SNP } & \multirow[b]{2}{*}{ Gene } & \multirow[b]{2}{*}{ Function } & \multicolumn{3}{|c|}{ Statistical significance } \\
\hline & & & $\begin{array}{l}\text { Risk of } \\
\text { HNC }\end{array}$ & $\begin{array}{l}\text { Risk of } \\
\text { recurrence }\end{array}$ & $\begin{array}{l}\text { Reduced } \\
\text { survival }\end{array}$ \\
\hline rs 1719153 & CCLA & Immune response & Yes & & \\
\hline rs2280789 & $C C L 5$ & Immune response & Yes & Yes* & \\
\hline rs2069705 & $I F N g$ & $\begin{array}{l}\text { Immune response, } \\
\text { inflammation }\end{array}$ & Yes & & \\
\hline rs6822844 & $I L 2$ & $\begin{array}{l}\text { Immune response, cell } \\
\text { growth }\end{array}$ & & Yes* & \\
\hline rs3790568 & $I L 12 R b 2$ & $\begin{array}{l}\text { Immune response, } \\
\text { inflammation }\end{array}$ & Yes & & Yes \\
\hline rs1800629 & $T N F a$ & $\begin{array}{l}\text { Immune response, } \\
\text { inflammation }\end{array}$ & Yes & Yes* & Yes \\
\hline rs1800610 & $T N F a$ & $\begin{array}{l}\text { Immune response, } \\
\text { inflammation }\end{array}$ & Yes & & \\
\hline rs 1801133 & MTHFR & Folate metabolism & Yes & & \\
\hline rs4444903 & $E G F$ & Epidermal growth factor & Yes* & & \\
\hline rs 1231204 & $P R K D C$ & DNA repair & Yes & & \\
\hline rs11571424 & $\operatorname{Rad} 52$ & DNA repair & Yes* & & \\
\hline rs 1045485 & Caspases 8 & Apoptosis & Yes & & \\
\hline rs 3758562 & Perforin & $\begin{array}{l}\text { Immune response, } \\
\text { cytolysis }\end{array}$ & Yes & Yes & \\
\hline rs10999426 & Perforin & $\begin{array}{l}\text { Immune response, } \\
\text { cytolysis }\end{array}$ & Yes** & Yes & \\
\hline
\end{tabular}

* Statistical significance when compairing male patients with male controls. ** Statistical significance when compairing female patients with female controls.

\section{Limitations}

When the groups were stratified on their SNP genotype it resulted in to small groups to analyse survival or recurrences according to TNM stage or tumor locations. Another limitation is that information about risk factors for HNC such as alcohol consumption, smoking, or HR-HPV status for the patients was missing. However, the difference in frequency of SNPs between references and patients might suggest a role of genetic factors in HNC. 


\section{Paper III}

The objective of this study was to examine biomarkers induced by cigarette smoking in healthy individuals. Circulating levels of WBCs and its 6 subpopulations, 11 plasma proteins or cytokines/chemokines, 11 plasma miRNAs and 5 SNPs associated with inflammatory cytokines, chemokines and proteins were analysed. Thirty nine current smokers and 101 individuals who had never used any tobacco product were included for this purpose.

Higher levels of total WBCs, neutrophils, monocytes, lymphocytes, CRP, MCP-1, IFN- $\gamma$ and lower levels of miR-21 were detected in smokers compared to non-smokers (Table 4).

Table 4. Circulating inflammatory or immune response associated biomarkers with statistically significant differences between smokers and non-smokers.

\begin{tabular}{lll}
\hline Biomarker & $\begin{array}{l}\text { Fold } \\
\text { change* }\end{array}$ & p-value \\
\hline WBC and subpopulations & & \\
Total WBCs & 1.3 & $<0.01$ \\
Neutrophils & 1.33 & $<0.01$ \\
Monocytes & 1.09 & $<0.01$ \\
Lymphocytes & 1.14 & $<0.01$ \\
Neutrophile/Lymphocyte ratio & 1.12 & 0.05 \\
Plasma protein and cytokine/chemokine & & \\
IFN- $\gamma$ & 1.77 & $<0.01$ \\
CRP & 1.38 & 0.01 \\
MCP-1 & 1.22 & 0.05 \\
MiRNA & & \\
miR-21 & 0.72 & 0.01 \\
& & \\
\hline
\end{tabular}

*Ratio of mean values between smokers and non-smokers.

To disclose a possible genetic influence on levels of inflammatory cytokines, chemokines or proteins, five SNPs in $I F N-\gamma$ (rs2069705, rs2069718), MCP-1 (rs2530797, rs2530797) and CRP (rs1800947) were selected since their plasma levels differed statistically significantly between smokers and non-smokers (Table 4). Statistically significantly higher levels of IFN- $\gamma$ in smokers was detected (median: $189.9 \mathrm{pg} / \mathrm{mL}, \mathrm{n}=39$ ) compared to non-smokers (median: $98.71 \mathrm{pg} / \mathrm{ml}, \mathrm{n}=101)$. An association to SNP was found, as statically significantly higher levels of IFN- $\gamma$ were seen among the smokers with rs2069705 AG/GG genotype (median: $213.9 \mathrm{pg} / \mathrm{mL}, \mathrm{n}=19$ ) compared to the non-smokers with AG/GG genotype (median: 88.0 
$\mathrm{pg} / \mathrm{mL}, \mathrm{n}=53$ ). No difference in the level of IFN- $\gamma$ was found between smokers and nonsmokers with AA genotype. Also, the IFN- $\gamma$ levels in smokers with AG/GG genotype (median: $213.9 \mathrm{pg} / \mathrm{mL}, \mathrm{n}=19$ ) was statistically significantly higher compared to smokers with AA genotype (median: $145.1 \mathrm{pg} / \mathrm{mL}, \mathrm{n}=20$ ) (Figure 2). No difference was detected when comparing AA and AG/GG genotypes of smokers and non-smokers.

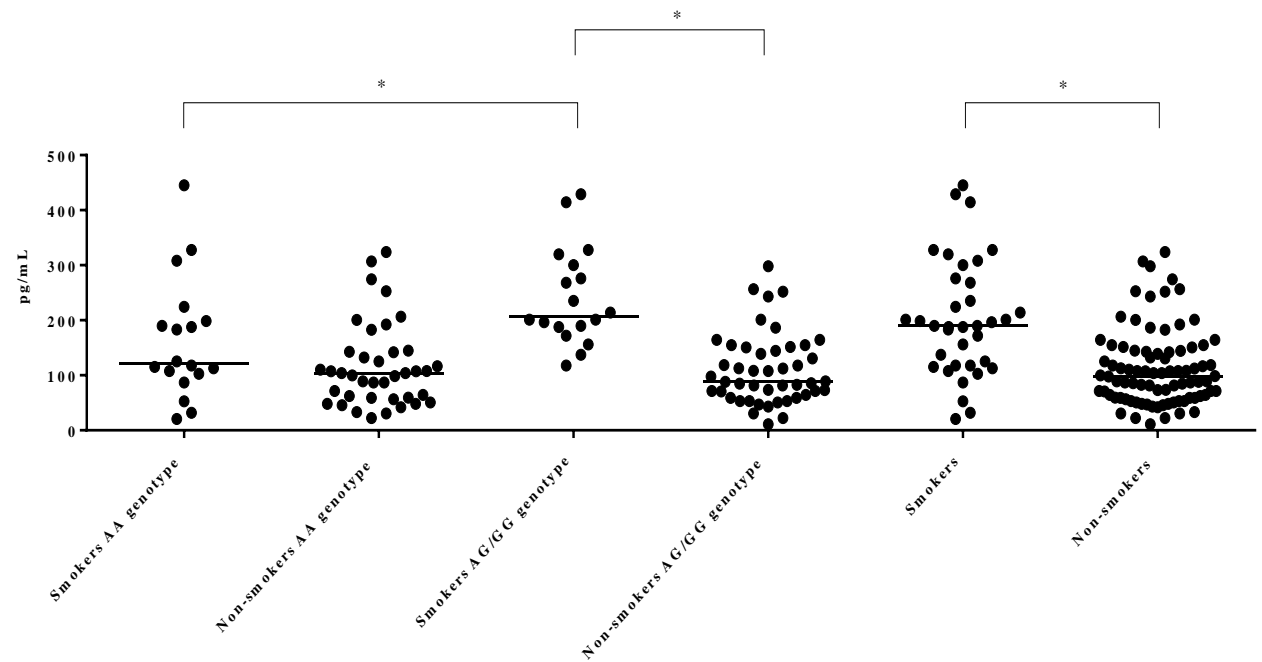

Figure 2. IFN- $\gamma$ levels of healthy individuals, stratified by rs206970 SNP genotypes and smoking status. The lines indicate median values. Statistically significant differences between smoking status and or SNP genotypes are indicated by asterisks.

\section{Limitations}

Adjustment was only done for age and gender, wheras information of other potential confounders in the immune response to smoking such as lung capacity, body mass index, type of cigarette smoked and individual smoking behavior were missing. The effect of SNP rs206970 and smoking on levels of IFN- $\gamma$ was based on a small number of individuals and needs to be confirmed on a larger cohort. An inclusion of further SNPs associated with IFN- $\gamma$ is also warranted. In the real time PCR analysis of miRNA, low levels or absence of miRNA were found in 10 miRNAs which had to be excluded from further analysis. This indicates a low sensitivity and in future analysis of miRNA from plasma, the Droplet Digital PCR or other high sensitive assays might be more suitable for plasma miRNA analysis. 


\section{Paper IV}

The objective of this study was to investigate the separate effects of smoking and HNC on 18 inflammatory or immune regulatory biomarkers and the impact of HR-HPV, age and gender on these biomarkers. The circulating levels of WBCs and six subpopulations, 11 plasma proteins or cytokines/chemokines were analysed and compared between smoking and nonsmoking patients, smoking and non-smoking controls and between patients and controls.

Patients had higher levels of WBCs, neutrophils, monocytes, NLR, CRP, IL-6, IFN- $\gamma$, MCP1, PDGF-BB, MIP-1b and TNF- $\alpha$, and lower levels of lymphocytes, IL-2 and IL-10 compared to controls.

Smoking had the highest impact on the variation of WBCs, IL-6, IFN- $\gamma$ and MCP-1 levels $(12 \%, 13 \%, 30 \%$ and $14 \%$, respectively). HNC had the highest impact on the variation of neutrophil, monocyte, NLR, CRP, MIP-1b and TNF- $\alpha$ levels $(18 \%, 11 \%, 20 \%, 24 \%, 11 \%$ and $11 \%$, respectively).

The impact of HNC or smoking on the variation of lymphocyte, eosinophil, basophil, IL-2, IL-10, Il-12, PDGF-bb and Rantes levels were between $1 \%$ and $8 \%$.

Gender had an impact between $2 \%$ and $7 \%$ on the variation of levels of monocytes, IL-2, IL6, IL-10, MCP-1, PDGF-BB, Rantes and TNF- $\alpha$. Age had an impact between $1 \%$ and $2 \%$ of the variation on levels of monocytes, IL-10, MIP-1b and TNF- $\alpha$. No impact of HR-HPV on the biomarker levels was detected.

\section{Limitations}

The impact of smoking and or HNC was lower than $30 \%$ on the variation of the analysed biomarker levels. There are other factors than the analysed variables smoking, HNC, age, gender and HR-HPV that influence the variation of the inflammatory biomarkers. Due to the small number of patients, a stratification of patients dependent on TNM stage or tumor location was not possible. Also, a follow-up sample collection after one year would have offered an opportunity to examine the impact of smoking and HNC on the immune system over time, compairing patients who had stopped smoking and continuous smoking patients. 


\section{Discussion}

We have studied some blood based, rapid and low cost biomarkers as possible complements to other clinical tools for HNC patient decisions. A possible genetic influence and the effect of smoking on the biomarker levels were also studied.

\section{Immune response in HNC patients}

The higher plasma levels of TNF- $\alpha$ and CRP found in HNC patients compared to controls (paper I) was confirmed in a different cohort of patients and controls (paper IV). The higher levels of IL-6 and lower levels of IL-2 detected in patients (paper I) reached statistical significance in paper IV. This, together with elevated levels of WBCs, neutrophils, monocytes, NLR, IFN- $\gamma$, MCP-1, PDGF-BB and MIP-1 $\beta$ (paper IV), indicates a systemic inflammation and immune suppression in HNC patients. Our findings confirm previous results (Millrud et al., 2012, Peter et al., 2013, Rachidi et al., 2016). The inflammatory activity in the patients could be dependent on the high mutation burden with high immune cell infiltrations in the TME (Giannakis et al., 2016). The high immune cell infiltration in the TME could indicate an anti-tumor immune response with a favorable outcome (Spranger and Gajewski, 2016). However, an elevated level of neutrophils and the elevated NLR (paper IV) indicates an impaired tumor immune response in the HNC patients.

An inflammatory stage was indicated by elevated levels of CRP and TNF- $\alpha$ in some patients. We detected, in paper I, that elevated levels of both CRP and TNF- $\alpha$ were significantly related to short survival time of HNC patients, independent of TNM stage or tumor location. When combining TNM stage and the plasma levels of CRP and TNF- $\alpha$, these biomarkers could identify patients with a lower risk of treatment failure despite high clinical TNM stage and patients with a higher risk of treatment failure, despite a lower clinical TNM stage. The definition of high or low levels of CRP and TNF- $\alpha$ in paper I, was done according to the mean values. Chen et al. defined elevated and non-elevated CRP levels based on the clinically mostly used level of $10 \mathrm{mg} / \mathrm{L}$ (Chen et al., 2019). They found that elevated levels before and after treatment were associated with poor prognosis for patients with nasopharyngeal HNC. Xia et al. used the level $2.46 \mathrm{mg} / \mathrm{L}$ to distinguish high and low levels of CRP and could predict poor prognosis for the HNC patients with high levels (Xia et al., 2013). The cut-off value for high and low CRP levels in HNC patients need to be further investigated before 
clinical implementation. Our results in paper IV revealed that the elevated levels of CRP and TNF- $\alpha$ was associated with HNC, with only a partial impact of smoking.

Although, an association of chronic inflammation and HR-HPV infections has been shown in oropharyngeal HNC patients (Tezal et al., 2012), we found no correlation of HR-HPV on the inflammatory biomarkers analysed. This indicates that HR-HPV infection has only minor impact on the inflammatory stage of HNC patients. This is in agreement with previous results (Stanley, 2006).

In addition to CRP, the highest impact of HNC was found on the levels of neutrophils and NLR. Neutrophils could suppress T-cell activation and proliferation (Treffers et al., 2016), and elevated levels of neutrophils are associated with lower levels of lymphocytes in HNC (Rachidi et al., 2016). The HNC related elevation of neutrophils and NLR (paper IV) indicates a tumor promoting effect related to the tumor with only a minor impact from smoking.

\section{Smoking effect on biomarkers}

Smoking induces a systemic inflammatory response with elevated levels of total WBCs, neutrophils, monocytes, lymphocytes, IFN- $\gamma$, CRP and MCP-1 in healthy smokers (paper III and IV). The NLR was not elevated in healthy smokers as a group (paper IV) but after adjustment for age and gender, a statistically significant elevation was seen (paper III).

The separate effects of smoking and HNC on the biomarkers were presented in paper IV. Smoking had a major impact on the elevated IFN- $\gamma$, WBCs and MCP-1 levels. Elevated levels of WBCs and/or various subpopulations are associated with other smoking related diseases such as CVD and lung cancer (Sharma et al., 2015, Sprague et al., 2008). The findings of elevated levels of MCP-1 in smoking individuals could reflect long term smoking and might be used as a biomarker for smoking duration (Komiyama et al., 2018). Elevated levels of MCP-1 could also indicate a higher risk for CVD and HNC progression ( $\mathrm{Ji}$ et al., 2014, Martinovic et al., 2005). The smoking associated inflammatory effect, as indicated by elevated levels of WBCs, could sustain up to five years after smoking cessation (Van Tiel et al., 2002). Not only cellular response, several tumor suppression genes and oncogenes could be dysregulated several years after cessation (Spira et al., 2004). 
Smoking had a higher impact than HNC, age and gender on the elevated levels of IFN- $\gamma$ (paper IV). In paper III, we found that the elevated level of IFN- $\gamma$ only was observed in healthy donors with IFN- $\gamma$ rs2069705 SNP genotype AG/GG. This indicates a genetic influence on the smoking effect. Also, epigenetic factors such as miRNA had an influence on the levels of IFN- $\gamma$, as we, in paper III, found that the increased levels of IFN- $\gamma$ in the healthy smokers correlated with the decreased levels of miR-21. This is in agreement with the result of $\mathrm{Lu}$ et al. They showed that deletion of the miR-21 gene in mice resulted in increased levels of IFN- $\gamma$ (Lu et al. 2011). IFN- $\gamma$ is a pleiotropic cytokine and could have dual functions in antitumor immunity, although it is generally considered to have favorable antitumor properties. miR-21 is regarded as a oncomir (Iorio and Croce, 2012) with increased expression levels in several cancers (Khalighfard et al., 2018, Xue et al., 2016) including HNC (Reis et al., 2010). Together, the increased levels of IFN- $\gamma$ and the decreased levels miR-21, could illustrate self-protective mechanisms against the carcinogenic compounds in cigarette smoke.

Healthy smoking controls had higher levels of neutrophils in comparison with non-smoking controls, but there was no effect on the NLR using Kruskal-Wallis test with Dunn's test (paper IV). However, by the use of a linear regression model adjusting for age and gender with a likelihood ratio test, to adopt the effect of smoking, a difference was seen in NLR in smokers compared to non-smokers. Higher NLR in healthy smokers compared to nonsmokers is in agreement with previous results (Tulgar et al., 2016, Gumus et al., 2018). An elevated NLR has been associated with increased risk for breast cancer (Fang et al., 2018), whereas this is not documented in HNC and needs further studies.

\section{SNP as biomarker of HNC}

Not all smokers develop smoking associated diseases. Thus, besides environmental factor such as smoking and HPV infections, genetics could be a part of the oncogenesis of HNC. We found that SNPs in immune associated genes were associated with cancer risk, tumor recurrence and the clinical outcome of HNC patients. One SNP in the promoting region of TNF- $\alpha$ gene, rs1800629, was associated with all three parameters in Caucasian HNC patients (paper II). This SNP variant, amongst others, in the TNF- $\alpha$ gene was shown to contribute to HPV 16 associated HNC cancer in oropharynx and oral cavity (Jin et al., 2013). The rs1800629 is also associated with the production of TNF- $\alpha$ (Wilson et al., 1997, Bouma et al., 1996). 
TNF- $\alpha$ is regarded as a pleiotropic cytokine with both tumor-necrotic and tumor-promoting activities and is considered as a pro-inflammatory mediator (Mocellin and Nitti, 2008). We found that elevated levels of TNF- $\alpha$, at time for diagnosis, were associated with shorter survival in HNC patients and the elevated levels seems to have a tumor promoting effect in these patients. The higher rate of recurrence and a shorter survival in patients with rs1800629 AA and AG genotypes could be due to an elevated level of TNF- $\alpha$ that we described in HNC patients, in paper I and paper IV. 


\section{Conclusions}

Blood based, rapid and low cost biomarkers are possible complements to clinical tools for HNC patient decisions. Separate effects of smoking and HNC on the levels of biomarkers were documented and a genetic influence on a smoking related biomarker was found. Our findings indicate that:

- Elevated levels of CRP and TNF- $\alpha$ in the patient plasma are related to shorter patient survival, independent of TNM stage.

- Plasma CRP and TNF- $\alpha$ in combination with TNM staging are suitable as biomarkers for predicting survival of $\mathrm{HNC}$ patients.

- SNPs in immune response genes such as rs1800629 in the TNF- $\alpha$ gene, indicates a risk for $\mathrm{HNC}$, risk for recurrence and a decreased survival in HNC patients.

- Both smoking and HNC induces a systemic inflammatory response

- Elevated levels of IFN- $\gamma$ marks a smoking associated inflammatory response and could have a genetic association indicated by an SNP in the IFN- $\gamma$ gene.

- A HNC related inflammatory response is reflected by elevated levels of neutrophils, NLR and CRP.

- Decreased levels of oncomiR-21 in healthy smokers could be a protective response to cigarette smoke. 


\section{Future perspectives}

Treatment results and survival among patients can be assumed not only to be due to tumor biology but also to host factors in the patient. These may be genetic, epigenetic or due to the TME or the smoking habits of the patients. Finding biomarkers to identify the risk and for predicting treatment results for this patient group is very important.

We have investigated blood based biomarkers which could indicate the risk of HNC, recurrence of the disease or the survival of HNC patients and how smoking could affect the immune response and found interesting result that need further studies.

Further studies are needed to verify the result from paper I on the survival of the patients in association to CRP and TNF- $\alpha$ levels. At first this will be done in HNC patients, included in paper IV.

Patients with HR-HPV related oropharyngeal HNC have a better prognosis than patients with HPV negative tumors. However, this effect of HR-HPV is not seen in HR-HPV positive smoking patients. It would be interesting to study what mechanisms influencing this smoking effect.

Cancer immunotherapy becomes more available as a treatment option and cancers with high TMB and high immunologic activity are suggested to benefit from this treatment. However, not all patients respond to this therapy and further studies, to identify biomarkers selecting patients to be treated, are warranted. Collaboration with other groups studying HNC is however required.

Not all smokers develop smoking related diseases. Future studies will continue to analyse biomarkers, for a prediction in who are at higher risk for develop smoking related diseases. 


\section{Acknowledgements}

Thank you all who have contributed and supported me in the completion of this thesis, especially to:

All the patients and healthy individuals for their contributions to this project.

My supervisor Nongnit Laytragoon Lewin, who introduced me to the research area. Always supportive with a positive attitude. Learning that everything could be solved.

Sture Löfgren, for all your help and guidance throughout this project. For teaching me the importance of writing clearly and concisely.

Freddi Lewin, for all the support and guidance in this project. For sharing your great knowledge of Oncology and HNC with me.

Mats Nilsson, for the help in the challenging area of statistics.

Delmy Olivia, for your energetic efforts in collecting samples of HNC patients.

Levar Shamoun, for your practical help in this project.

My co-supervisor Pierre Åman, for advices and generous help in this project.

My co-authors in the articles, especially Lars-Erik Rutqvist, for your contributions and constructive comments.

Emma and Stina for supporting me in this project and for fun times in and outside the lab.

My colleagues at Department of Microbiology and Utvecklingsenheten, Jönköping County Hospital, for all the support and help throughout the years.

My colleagues at the Blood Bank Center, Laboratory medicine, Jönköping County Hospital, for your efforts in recruiting healthy blood donors to the studies.

My colleagues at The Department of Clinical Pathology, Laboratory medicine, Jönköping County Hospital, for the help in analyzes and interpretation of HPV status in FFPE tumor tissues.

My colleagues at the Department of Clinical Chemistry, Laboratory medicine, Jönköping County Hospital for the help in the CRP and WBC count with differential analyses. 
Tomas Axelsson at SNP\&SEQ Technology Platform, Uppsala University for advices, support and practical help in the SNP analyses.

My bosses, Johanna Rundbäck and Hanna Odén Poulsen for your support and giving me the opportunity to do research.

My dear wife Lena and our lovely daughters Matilda and Elvira, for giving me happiness, understanding and support during all the years.

Futurum - the academy for health and care, Region Jönköping County, Laboratory medicine, Jönköping County Hospital, Foundation of Clinical Cancer Research, Jönköping, Medical Research Council of Southeast Sweden and Swedish Laryngeal Foundation for financial support. 


\section{References}

ACHARYA, S., KALE, J., HALLIKERI, K., ANEHOSUR, V. \& ARNOLD, D. 2018. Clinical significance of preoperative serum C-reactive protein in oral squamous cell carcinoma. Int J Oral Maxillofac Surg, 47, 16-23.

ADAMI, J., GABEL, H., LINDELOF, B., EKSTROM, K., RYDH, B., GLIMELIUS, B., EKBOM, A., ADAMI, H. O. \& GRANATH, F. 2003. Cancer risk following organ transplantation: a nationwide cohort study in Sweden. Br J Cancer, 89, 1221-7.

AL-QAHTANI, D., ANIL, S. \& RAJENDRAN, R. 2011. Tumour infiltrating CD25+ FoxP3+ regulatory $\mathrm{T}$ cells (Tregs) relate to tumour grade and stromal inflammation in oral squamous cell carcinoma. J Oral Pathol Med, 40, 636-42.

ALDASORO ARGUINANO, A. A., DADE, S., STATHOPOULOU, M., DERIVE, M., COUMBA NDIAYE, N., XIE, T., MASSON, C., GIBOT, S. \& VISVIKIS-SIEST, S. 2017. TREM-1 SNP rs2234246 regulates TREM-1 protein and mRNA levels and is associated with plasma levels of L-selectin. PLoS One, 12, e0182226.

ALLES, J., FEHLMANN, T., FISCHER, U., BACKES, C., GALATA, V., MINET, M., HART, M., ABU-HALIMA, M., GRÄSSER, F. A., LENHOF, H.-P., KELLER, A. \& MEESE, E. 2019. An estimate of the total number of true human miRNAs. Nucleic Acids Research, 47, 3353-3364.

ALLIN, K. H., BOJESEN, S. E. \& NORDESTGAARD, B. G. 2009. Baseline C-reactive protein is associated with incident cancer and survival in patients with cancer. J Clin Oncol, 27, 2217-24.

ANANTHARAMAN, D., MARRON, M., LAGIOU, P., SAMOLI, E., AHRENS, W., POHLABELN, H., SLAMOVA, A., SCHEJBALOVA, M., MERLETTI, F., RICHIARDI, L., KJAERHEIM, K., CASTELLSAGUE, X., AGUDO, A., TALAMINI, R., BARZAN, L., MACFARLANE, T. V., TICKLE, M., SIMONATO, L., CANOVA, C., CONWAY, D. I., MCKINNEY, P. A., THOMSON, P., ZNAOR, A., HEALY, C. M., MCCARTAN, B. E., HASHIBE, M., BRENNAN, P. \& MACFARLANE, G. J. 2011. Population attributable risk of tobacco and alcohol for upper aerodigestive tract cancer. Oral Oncol, 47, 725-31.

ANDERSSON, B. A., LEWIN, F., LUNDGREN, J., NILSSON, M., RUTQVIST, L. E., LOFGREN, S. \& LAYTRAGOON-LEWIN, N. 2014. Plasma tumor necrosis factoralpha and C-reactive protein as biomarker for survival in head and neck squamous cell carcinoma. J Cancer Res Clin Oncol, 140, 515-9.

ANDERSSON, E., TORESSON GRIP, E., NORRLID, H. \& FRIDHAMMAR, A. 2017. Samhällskostnad för rökningsrelaterad sjuklighet i Sverige, IHE, Institutet för Hälsooch Sjukvårdsekonomi, Lund, Sweden.

ANG, K. K., HARRIS, J., WHEELER, R., WEBER, R., ROSENTHAL, D. I., NGUYENTAN, P. F., WESTRA, W. H., CHUNG, C. H., JORDAN, R. C., LU, C., KIM, H., AXELROD, R., SILVERMAN, C. C., REDMOND, K. P. \& GILLISON, M. L. 2010. Human papillomavirus and survival of patients with oropharyngeal cancer. $N$ Engl J Med, 363, 24-35.

ARNSON, Y., SHOENFELD, Y. \& AMITAL, H. 2010. Effects of tobacco smoke on immunity, inflammation and autoimmunity. J Autoimmun, 34, J258-65.

BADOUAL, C., HANS, S., RODRIGUEZ, J., PEYRARD, S., KLEIN, C., AGUEZNAY NEL, H., MOSSERI, V., LACCOURREYE, O., BRUNEVAL, P., FRIDMAN, W. H., BRASNU, D. F. \& TARTOUR, E. 2006. Prognostic value of tumor-infiltrating CD4+ T-cell subpopulations in head and neck cancers. Clin Cancer Res, 12, 465-72. 
BAKER, R. R. 2006. Smoke generation inside a burning cigarette: Modifying combustion to develop cigarettes that may be less hazardous to health. Progress in Energy and Combustion Science, 325, 373-385.

BARTEL, D. P. 2009. MicroRNAs: target recognition and regulatory functions. Cell, 136, 215-33.

BECHER, H., RAMROTH, H., AHRENS, W., RISCH, A., SCHMEZER, P. \& DIETZ, A. 2005. Occupation, exposure to polycyclic aromatic hydrocarbons and laryngeal cancer risk. Int J Cancer, 116, 451-7.

BERKHOUT, R. J., BOUWES BAVINCK, J. N. \& TER SCHEGGET, J. 2000. Persistence of human papillomavirus DNA in benign and (pre)malignant skin lesions from renal transplant recipients. J Clin Microbiol, 38, 2087-96.

BOBDEY, S., GANESH, B., MISHRA, P. \& JAIN, A. 2017. Role of Monocyte Count and Neutrophil-to-Lymphocyte Ratio in Survival of Oral Cancer Patients. Int Arch Otorhinolaryngol, 21, 21-27.

BORGERDING, M. \& KLUS, H. 2005. Analysis of complex mixtures--cigarette smoke. Exp Toxicol Pathol, 57 Suppl 1, 43-73.

BORISH, L. C. \& STEINKE, J. W. 2003. 2. Cytokines and chemokines. J Allergy Clin Immunol, 111, S460-75.

BOSCOLO-RIZZO, P., ZORZI, M., DEL MISTRO, A., DA MOSTO, M. C., TIRELLI, G., BUZZONI, C., RUGGE, M., POLESEL, J., GUZZINATI, S. \& GROUP, A. W. 2018. The evolution of the epidemiological landscape of head and neck cancer in Italy: Is there evidence for an increase in the incidence of potentially HPV-related carcinomas? PloS one, 13, e0192621-e0192621.

BOSE, A., CHAKRABORTY, T., CHAKRABORTY, K., PAL, S. \& BARAL, R. 2008. Dysregulation in immune functions is reflected in tumor cell cytotoxicity by peripheral blood mononuclear cells from head and neck squamous cell carcinoma patients. Cancer Immun, 8, 10.

BOUMA, G., CRUSIUS, J. B., OUDKERK POOL, M., KOLKMAN, J. J., VON BLOMBERG, B. M., KOSTENSE, P. J., GIPHART, M. J., SCHREUDER, G. M., MEUWISSEN, S. G. \& PENA, A. S. 1996. Secretion of tumour necrosis factor alpha and lymphotoxin alpha in relation to polymorphisms in the TNF genes and HLA-DR alleles. Relevance for inflammatory bowel disease. Scand J Immunol, 43, 456-63.

BOURGUIGNON, L. Y., EARLE, C., WONG, G., SPEVAK, C. C. \& KRUEGER, K. 2012. Stem cell marker (Nanog) and Stat-3 signaling promote MicroRNA-21 expression and chemoresistance in hyaluronan/CD44-activated head and neck squamous cell carcinoma cells. Oncogene, 31, 149-60.

BRAY, F., FERLAY, J., SOERJOMATARAM, I., SIEGEL, R. L., TORRE, L. A. \& JEMAL, A. 2018. Global cancer statistics 2018: GLOBOCAN estimates of incidence and mortality worldwide for 36 cancers in 185 countries. CA Cancer J Clin, 68, 394-424.

BRIERLEY JD, G. M., WITTEKIND C (ed.) 2017. The TNM classification of malignant tumours. 8th edn., Oxford: Wiley Blackwell.

BROOKES, A. J. 1999. The essence of SNPs. Gene, 234, 177-86.

BROWN, K. F., RUMGAY, H., DUNLOP, C., RYAN, M., QUARTLY, F., COX, A., DEAS, A., ELLISS-BROOKES, L., GAVIN, A., HOUNSOME, L., HUWS, D., ORMISTON-SMITH, N., SHELTON, J., WHITE, C. \& PARKIN, D. M. 2018. The fraction of cancer attributable to modifiable risk factors in England, Wales, Scotland, Northern Ireland, and the United Kingdom in 2015. Br J Cancer, 118, 1130-1141. 
BURKHOLDER, B., HUANG, R. Y., BURGESS, R., LUO, S., JONES, V. S., ZHANG, W., LV, Z. Q., GAO, C. Y., WANG, B. L., ZHANG, Y. M. \& HUANG, R. P. 2014. Tumor-induced perturbations of cytokines and immune cell networks. Biochim Biophys Acta, 1845, 182-201.

BUSSU, F., GRAZIANI, C., GALLUS, R., CITTADINI, A., GALLI, J., DE CORSO, E., DI CINTIO, G., CORBI, M., ALMADORI, G., BONINSEGNA, A., PALUDETTI, G. \& SGAMBATO, A. 2018. IFN- $\gamma$ and other serum cytokines in head and neck squamous cell carcinomas. Acta otorhinolaryngologica Italica : organo ufficiale della Societa italiana di otorinolaringologia e chirurgia cervico-facciale, 38, 94-102.

CAMPBELL, K. S. \& PURDY, A. K. 2011. Structure/function of human killer cell immunoglobulin-like receptors: lessons from polymorphisms, evolution, crystal structures and mutations. Immunology, 132, 315-325.

CAO, W., LIU, Z., GOKAVARAPU, S., CHEN, Y., YANG, R. \& JI, T. 2016. Reformed smokers have survival benefits after head and neck cancer. Br J Oral Maxillofac Surg, $54,818-25$.

CHALMERS, Z. R., CONNELLY, C. F., FABRIZIO, D., GAY, L., ALI, S. M., ENNIS, R., SCHROCK, A., CAMPBELL, B., SHLIEN, A., CHMIELECKI, J., HUANG, F., HE, Y., SUN, J., TABORI, U., KENNEDY, M., LIEBER, D. S., ROELS, S., WHITE, J., OTTO, G. A., ROSS, J. S., GARRAWAY, L., MILLER, V. A., STEPHENS, P. J. \& FRAMPTON, G. M. 2017. Analysis of 100,000 human cancer genomes reveals the landscape of tumor mutational burden. Genome medicine, 9, 34-34.

CHAN, T. A., YARCHOAN, M., JAFFEE, E., SWANTON, C., QUEZADA, S. A., STENZINGER, A. \& PETERS, S. 2019. Development of tumor mutation burden as an immunotherapy biomarker: utility for the oncology clinic. Annals of oncology: official journal of the European Society for Medical Oncology, 30, 44-56.

CHANG, K. P., KAO, H. K., WU, C. C., FANG, K. H., CHANG, Y. L., HUANG, Y. C., LIU, S. C. \& CHENG, M. H. 2013. Pretreatment interleukin-6 serum levels are associated with patient survival for oral cavity squamous cell carcinoma. Otolaryngol Head Neck Surg, 148, 786-91.

CHATURVEDI, A. K. 2012. Epidemiology and clinical aspects of HPV in head and neck cancers. Head Neck Pathol, 6 Suppl 1, S16-24.

CHEN, A. M., CHEN, L. M., VAUGHAN, A., SREERAMAN, R., FARWELL, D. G., LUU, Q., LAU, D. H., STUART, K., PURDY, J. A. \& VIJAYAKUMAR, S. 2011. Tobacco smoking during radiation therapy for head-and-neck cancer is associated with unfavorable outcome. Int J Radiat Oncol Biol Phys, 79, 414-9.

CHEN, F., ZHUANG, X., LIN, L., YU, P., WANG, Y., SHI, Y., HU, G. \& SUN, Y. 2015.

New horizons in tumor microenvironment biology: challenges and opportunities. BMC medicine, 13, 45-45.

CHEN, R., ZHOU, Y., YUAN, Y., ZHANG, Q., HE, S., CHEN, Y. \& REN, Y. 2019. Effect of CRP and Kinetics of CRP in Prognosis of Nasopharyngeal Carcinoma. Frontiers in oncology, 9, 89-89.

CHIKAMATSU, K., SAKAKURA, K., TOYODA, M., TAKAHASHI, K., YAMAMOTO, T. \& MASUYAMA, K. 2012. Immunosuppressive activity of CD14+ HLA-DR- cells in squamous cell carcinoma of the head and neck. Cancer Science, 103, 976-983.

CHIKAMATSU, K., SAKAKURA, K., WHITESIDE, T. L. \& FURUYA, N. 2007. Relationships between regulatory $\mathrm{T}$ cells and CD8+ effector populations in patients with squamous cell carcinoma of the head and neck. Head Neck, 29, 120-7.

CHUA, M. L. K., WEE, J. T. S., HUI, E. P. \& CHAN, A. T. C. 2016. Nasopharyngeal carcinoma. Lancet, 387, 1012-1024. 
COFFELT, S. B., WELLENSTEIN, M. D. \& DE VISSER, K. E. 2016. Neutrophils in cancer: neutral no more. Nature Reviews Cancer, 16, 431.

DAHLGREN, L., DAHLSTRAND, H. M., LINDQUIST, D., HOGMO, A., BJORNESTAL, L., LINDHOLM, J., LUNDBERG, B., DALIANIS, T. \& MUNCK-WIKLAND, E. 2004. Human papillomavirus is more common in base of tongue than in mobile tongue cancer and is a favorable prognostic factor in base of tongue cancer patients. Int $J$ Cancer, 112, 1015-9.

DATTA, S., CHATURVEDI, P., MISHRA, A. \& PAWAR, P. 2014. A review of Indian literature for association of smokeless tobacco with malignant and premalignant diseases of head and neck region. Indian J Cancer, 51, 200-208.

DE VILLIERS, E. M., FAUQUET, C., BROKER, T. R., BERNARD, H. U. \& ZUR HAUSEN, H. 2004. Classification of papillomaviruses. Virology, 324, 17-27.

DEPRAETERE, S., WILLEMS, J. \& JONIAU, M. 1991. Stimulation of CRP secretion in HepG2 cells: cooperative effect of dexamethasone and interleukin 6. Agents Actions, 34, 369-75.

DOLL, R. 1996. Nature and nurture: possibilities for cancer control. Carcinogenesis, 17, 17784.

DU CLOS, T. W. 2000. Function of C-reactive protein. Ann Med, 32, 274-8.

DUFFY, S. A., TAYLOR, J. M., TERRELL, J. E., ISLAM, M., LI, Y., FOWLER, K. E., WOLF, G. T. \& TEKNOS, T. N. 2008. Interleukin-6 predicts recurrence and survival among head and neck cancer patients. Cancer, 113, 750-7.

DUPONT, N. C., WANG, K., WADHWA, P. D., CULHANE, J. F. \& NELSON, E. L. 2005. Validation and comparison of luminex multiplex cytokine analysis kits with ELISA: determinations of a panel of nine cytokines in clinical sample culture supernatants. $J$ Reprod Immunol, 66, 175-91.

DURAY, A., DEMOULIN, S., HUBERT, P., DELVENNE, P. \& SAUSSEZ, S. 2010. Immune suppression in head and neck cancers: a review. Clin Dev Immunol, 2010, 701657.

ELDEEB, H., MACMILLAN, C., ELWELL, C. \& HAMMOD, A. 2012. The effect of the surgical margins on the outcome of patients with head and neck squamous cell carcinoma: single institution experience. Cancer biology \& medicine, 9, 29-33.

ELTING, L. S., KEEFE, D. M., SONIS, S. T., GARDEN, A. S., SPIJKERVET, F. K., BARASCH, A., TISHLER, R. B., CANTY, T. P., KUDRIMOTI, M. K. \& VERALLONCH, M. 2008. Patient-reported measurements of oral mucositis in head and neck cancer patients treated with radiotherapy with or without chemotherapy: demonstration of increased frequency, severity, resistance to palliation, and impact on quality of life. Cancer, 113, 2704-13.

FANG, Q., TONG, Y. W., WANG, G., ZHANG, N., CHEN, W. G., LI, Y. F., SHEN, K. W., WU, B. W. \& CHEN, X. S. 2018. Neutrophil-to-lymphocyte ratio, obesity, and breast cancer risk in Chinese population. Medicine (Baltimore), 97, e11692.

FERLITO, A., SHAHA, A. R., SILVER, C. E., RINALDO, A. \& MONDIN, V. 2001. Incidence and sites of distant metastases from head and neck cancer. ORL $J$ Otorhinolaryngol Relat Spec, 63, 202-7.

FERREIRA, F. O., RIBEIRO, F. L. L., BATISTA, A. C., LELES, C. R., DE CÁSSIA GONÇALVES ALENCAR, R. \& SILVA, T. A. 2008. Association of CCL2 with Lymph Node Metastasis and Macrophage Infiltration in Oral Cavity and Lip Squamous Cell Carcinoma. Tumor Biology, 29, 114-121.

FERRIS, R. L. 2015. Immunology and Immunotherapy of Head and Neck Cancer. Journal of clinical oncology : official journal of the American Society of Clinical Oncology, 33, 3293-3304. 
FOLKHÄLSOMYNDIGHETEN. 2019. Daglig tobaksrökning [Online]. Available: https://www.folkhalsomyndigheten.se/folkhalsorapportering-statistik/folkhalsansutveckling/levnadsvanor/tobaksrokning-daglig/ [Accessed 14 Aug 2019].

FRAZER, I. H., LEGGATT, G. R. \& MATTAROLLO, S. R. 2011. Prevention and treatment of papillomavirus-related cancers through immunization. Annu Rev Immunol, 29, 11138.

FREEDMAN, N. D., SCHATZKIN, A., LEITZMANN, M. F., HOLLENBECK, A. R. \& ABNET, C. C. 2007. Alcohol and head and neck cancer risk in a prospective study. $\mathrm{Br}$ J Cancer, 96, 1469-74.

FRIDLENDER, Z. G. \& ALBELDA, S. M. 2012. Tumor-associated neutrophils: friend or foe? Carcinogenesis, 33, 949-55.

GABRILOVICH, D. I. \& NAGARAJ, S. 2009. Myeloid-derived suppressor cells as regulators of the immune system. Nat Rev Immunol, 9, 162-74.

GAJEWSKI, T. F., SCHREIBER, H. \& FU, Y.-X. 2013. Innate and adaptive immune cells in the tumor microenvironment. Nature immunology, 14, 1014-1022.

GANCI, F., SACCONI, A., MANCIOCCO, V., SPERDUTI, I., BATTAGLIA, P., COVELLO, R., MUTI, P., STRANO, S., SPRIANO, G., FONTEMAGGI, G. \& BLANDINO, G. 2016. MicroRNA expression as predictor of local recurrence risk in oral squamous cell carcinoma. Head Neck, 38 Suppl 1, E189-97.

GAUR, P., SINGH, A. K., SHUKLA, N. K. \& DAS, S. N. 2014. Inter-relation of Th1, Th2, Th17 and Treg cytokines in oral cancer patients and their clinical significance. Hum Immunol, 75, 330-7.

GHAI, V. \& WANG, K. 2016. Recent progress toward the use of circulating microRNAs as clinical biomarkers. Arch Toxicol, 90, 2959-2978.

GIANNAKIS, M., MU, X. J., SHUKLA, S. A., QIAN, Z. R., COHEN, O., NISHIHARA, R., BAHL, S., CAO, Y., AMIN-MANSOUR, A., YAMAUCHI, M., SUKAWA, Y., STEWART, C., ROSENBERG, M., MIMA, K., INAMURA, K., NOSHO, K., NOWAK, J. A., LAWRENCE, M. S., GIOVANNUCCI, E. L., CHAN, A. T., NG, K., MEYERHARDT, J. A., VAN ALLEN, E. M., GETZ, G., GABRIEL, S. B., LANDER, E. S., WU, C. J., FUCHS, C. S., OGINO, S. \& GARRAWAY, L. A. 2016. Genomic Correlates of Immune-Cell Infiltrates in Colorectal Carcinoma. Cell Rep, 15, 857-865.

GOODCHILD, M., NARGIS, N., TURSAN, D. \& ESPAIGNET, E. 2018. Global economic cost of smoking-attributable diseases. Tobacco Control, 27, 58.

GRIFFITH, J. W., SOKOL, C. L. \& LUSTER, A. D. 2014. Chemokines and chemokine receptors: positioning cells for host defense and immunity. Annu Rev Immunol, 32, 659-702.

GRIVENNIKOV, S. I., GRETEN, F. R. \& KARIN, M. 2010. Immunity, inflammation, and cancer. Cell, 140, 883-99.

GROOPMAN, J. E. \& ITRI, L. M. 1999. Chemotherapy-induced anemia in adults: incidence and treatment. J Natl Cancer Inst, 91, 1616-34.

GUIZARD, A.-V. N., DEJARDIN, O. J., LAUNAY, L. C., BARA, S., LAPÔTRE-LEDOUX, B. M., BABIN, E. B., LAUNOY, G. D. \& LIGIER, K. A. 2017. Diagnosis and management of head and neck cancers in a high-incidence area in France: A population-based study. Medicine, 96, e7285-e7285.

GUMUS, F., SOLAK, I. \& ERYILMAZ, M. A. 2018. The effects of smoking on neutrophil/lymphocyte, platelet//lymphocyte ratios. Bratisl Lek Listy, 119, 116-119.

GUTHERY, S. L., SALISBURY, B. A., PUNGLIYA, M. S., STEPHENS, J. C. \& BAMSHAD, M. 2007. The structure of common genetic variation in United States populations. American journal of human genetics, 81, 1221-1231. 
HAHN, W. C. \& WEINBERG, R. A. 2002. Rules for making human tumor cells. $N$ Engl J Med, 347, 1593-603.

HALL, S. F., GROOME, P. A. \& ROTHWELL, D. 2000. The impact of comorbidity on the survival of patients with squamous cell carcinoma of the head and neck. Head Neck, $22,317-22$.

HAMMARSTEDT, L., LINDQUIST, D., DAHLSTRAND, H., ROMANITAN, M., DAHLGREN, L. O., JONEBERG, J., CRESON, N., LINDHOLM, J., YE, W., DALIANIS, T. \& MUNCK-WIKLAND, E. 2006. Human papillomavirus as a risk factor for the increase in incidence of tonsillar cancer. Int J Cancer, 119, 2620-3.

HASTIE, C. E., HAW, S. \& PELL, J. P. 2008. Impact of smoking cessation and lifetime exposure on C-reactive protein. Nicotine Tob Res, 10, 637-42.

HATCHER, J. L., STERBA, K. R., TOOZE, J. A., DAY, T. A., CARPENTER, M. J., ALBERG, A. J., SULLIVAN, C. A., FITZGERALD, N. C. \& WEAVER, K. E. 2016. Tobacco use and surgical outcomes in patients with head and neck cancer. Head Neck, $38,700-6$.

HECHT, S. S. 2003. Tobacco carcinogens, their biomarkers and tobacco-induced cancer. Nat Rev Cancer, 3, 733-44.

HECHT, S. S. 2012. Lung carcinogenesis by tobacco smoke. Int J Cancer, 131, 2724-32.

HECHT, S. S. \& SZABO, E. 2014. Fifty Years of Tobacco Carcinogenesis Research: From Mechanisms to Early Detection and Prevention of Lung Cancer. Cancer Prevention Research, 7, 1-8.

HEIKKILA, K., EBRAHIM, S. \& LAWLOR, D. A. 2007. A systematic review of the association between circulating concentrations of $\mathrm{C}$ reactive protein and cancer. $J$ Epidemiol Community Health, 61, 824-33.

HENRY, N. L. \& HAYES, D. F. 2012. Cancer biomarkers. Mol Oncol, 6, 140-6.

HEROIU CATALOIU, A.-D., DANCIU, C. E. \& POPESCU, C. R. 2013. Multiple cancers of the head and neck. Maedica, 8, 80-85.

HIRAOKA, N., ONOZATO, K., KOSUGE, T. \& HIROHASHI, S. 2006. Prevalence of FOXP3+ regulatory $\mathrm{T}$ cells increases during the progression of pancreatic ductal adenocarcinoma and its premalignant lesions. Clin Cancer Res, 12, 5423-34.

HO, A. S., KRAUS, D. H., GANLY, I., LEE, N. Y., SHAH, J. P. \& MORRIS, L. G. 2014. Decision making in the management of recurrent head and neck cancer. Head Neck, $36,144-51$.

IARC WORKING GROUP ON THE EVALUATION OF CARCINOGENIC RISKS TO HUMANS 2004. Betel-quid and areca-nut chewing and some areca-nut derived nitrosamines. IARC Monogr Eval Carcinog Risks Hum, 85, 1-334.

INSINGA, R. P., PEREZ, G., WHEELER, C. M., KOUTSKY, L. A., GARLAND, S. M., LEODOLTER, S., JOURA, E. A., FERRIS, D. G., STEBEN, M., BROWN, D. R., ELBASHA, E. H., PAAVONEN, J. \& HAUPT, R. M. 2010. Incidence, duration, and reappearance of type-specific cervical human papillomavirus infections in young women. Cancer Epidemiol Biomarkers Prev, 19, 1585-94.

IORIO, M. V. \& CROCE, C. M. 2012. MicroRNA dysregulation in cancer: diagnostics, monitoring and therapeutics. A comprehensive review. EMBO Mol Med, 4, 143-59.

JHA, P., RAMASUNDARAHETTIGE, C., LANDSMAN, V., ROSTRON, B., THUN, M., ANDERSON, R. N., MCAFEE, T. \& PETO, R. 2013. 21st-century hazards of smoking and benefits of cessation in the United States. N Engl J Med, 368, 341-50.

JI, W. T., CHEN, H. R., LIN, C. H., LEE, J. W. \& LEE, C. C. 2014. Monocyte chemotactic protein 1 (MCP-1) modulates pro-survival signaling to promote progression of head and neck squamous cell carcinoma. PLoS One, 9, e88952. 
JIN, L., STURGIS, E. M., ZHANG, Y., HUANG, Z., SONG, X., LI, C., WEI, Q. \& LI, G. 2013. Association of tumor necrosis factor-alpha promoter variants with risk of HPVassociated oral squamous cell carcinoma. Mol Cancer, 12, 80.

KASHIGAR, A., HABBOUS, S., ENG, L., IRISH, B., BISSADA, E., IRISH, J., BROWN, D., GILBERT, R., GULLANE, P., XU, W., HUANG, S. H., WITTERICK, I., FREEMAN, J., O'SULLIVAN, B., WALDRON, J., LIU, G. \& GOLDSTEIN, D. 2013. Social environment, secondary smoking exposure, and smoking cessation among head and neck cancer patients. Cancer, 119, 2701-9.

KATANO, A., TAKAHASHI, W., YAMASHITA, H., YAMAMOTO, K., ANDO, M., YOSHIDA, M., SAITO, Y., ABE, O. \& NAKAGAWA, K. 2017. The impact of elevated C-reactive protein level on the prognosis for oro-hypopharynx cancer patients treated with radiotherapy. Scientific reports, 7, 17805-17805.

KERR, D. A., SWEENEY, B., ARPIN, R. N., 3RD, RING, M., PITMAN, M. B., WILBUR, D. C. \& FAQUIN, W. C. 2016. Automated Extraction of Formalin-Fixed, ParaffinEmbedded Tissue for High-Risk Human Papillomavirus Testing of Head and Neck Squamous Cell Carcinomas Using the Roche Cobas 4800 System. Arch Pathol Lab Med, 140, 844-8.

KHALIGHFARD, S., ALIZADEH, A. M., IRANI, S. \& OMRANIPOUR, R. 2018. Plasma miR-21, miR-155, miR-10b, and Let-7a as the potential biomarkers for the monitoring of breast cancer patients. Sci Rep, 8, 17981.

KOMIYAMA, M., TAKANABE, R., ONO, K., SHIMADA, S., WADA, H., YAMAKAGE, H., SATOH-ASAHARA, N., MORIMOTO, T., SHIMATSU, A., TAKAHASHI, Y. \& HASEGAWA, K. 2018. Association between monocyte chemoattractant protein-1 and blood pressure in smokers. J Int Med Res, 46, 965-974.

KORRER, M. J. \& KIM, Y. 2017. Natural Killer cells from primary human head and neck squamous cell carcinomas upregulate NKG2A. The Journal of Immunology, 198, 130.18 .

KOSHIOL, J. E., SCHROEDER, J. C., JAMIESON, D. J., MARSHALL, S. W., DUERR, A., HEILIG, C. M., SHAH, K. V., KLEIN, R. S., CU-UVIN, S., SCHUMAN, P., CELENTANO, D. \& SMITH, J. S. 2006. Time to clearance of human papillomavirus infection by type and human immunodeficiency virus serostatus. Int J Cancer, 119, 1623-9.

KREIMER, A. R., CLIFFORD, G. M., BOYLE, P. \& FRANCESCHI, S. 2005. Human papillomavirus types in head and neck squamous cell carcinomas worldwide: a systematic review. Cancer Epidemiol Biomarkers Prev, 14, 467-75.

KRUSE, A. L., LUEBBERS, H. T. \& GRATZ, K. W. 2010. C-reactive protein levels: a prognostic marker for patients with head and neck cancer? Head Neck Oncol, 2, 21.

KUMAR, A., BHARTIYA, D., KAUR, J., KUMARI, S., SINGH, H., SARAF, D., SINHA, D. N. \& MEHROTRA, R. 2018. Regulation of toxic contents of smokeless tobacco products. Indian J Med Res, 148, 14-24.

KUSS, I., HATHAWAY, B., FERRIS, R. L., GOODING, W. \& WHITESIDE, T. L. 2004. Decreased absolute counts of T lymphocyte subsets and their relation to disease in squamous cell carcinoma of the head and neck. Clin Cancer Res, 10, 3755-62.

LAM, J. K. S., SUNDARESAN, P., GEBSKI, V. \& VENESS, M. J. 2018.

Immunocompromised patients with metastatic cutaneous nodal squamous cell carcinoma of the head and neck: Poor outcome unrelated to the index lesion. Head Neck, 40, 985-992.

LATHERS, D. M., ACHILLE, N. J. \& YOUNG, M. R. 2003. Incomplete Th2 skewing of cytokines in plasma of patients with squamous cell carcinoma of the head and neck. Hum Immunol, 64, 1160-6. 
LEBIEN, T. W. \& TEDDER, T. F. 2008. B lymphocytes: how they develop and function. Blood, 112, 1570-80.

LECHNER, A., SCHLOSSER, H., ROTHSCHILD, S. I., THELEN, M., REUTER, S., ZENTIS, P., SHIMABUKURO-VORNHAGEN, A., THEURICH, S., WENNHOLD, K., GARCIA-MARQUEZ, M., THARUN, L., QUAAS, A., SCHAUSS, A., ISENSEE, J., HUCHO, T., HUEBBERS, C., VON BERGWELT-BAILDON, M. \& BEUTNER, D. 2017. Characterization of tumor-associated T-lymphocyte subsets and immune checkpoint molecules in head and neck squamous cell carcinoma. Oncotarget, 8, 44418-44433.

LEE, C. H., LEE, K. W., FANG, F. M., WU, D. C., TSAI, S. M., CHEN, P. H., SHIEH, T. Y., CHEN, C. H., WU, I. C., HUANG, H. L., CHEN, B. H., CHANG, C. H., CHEN, M. K., CHOU, S. H., TSAI, Y. S., CHIANG, S. L. \& KO, Y. C. 2012a. The neoplastic impact of tobacco-free betel-quid on the histological type and the anatomical site of aerodigestive tract cancers. Int J Cancer, 131, E733-43.

LEE, J., TANEJA, V. \& VASSALLO, R. 2012b. Cigarette smoking and inflammation: cellular and molecular mechanisms. J Dent Res, 91, 142-9.

LEEMANS, C. R., BRAAKHUIS, B. J. \& BRAKENHOFF, R. H. 2011. The molecular biology of head and neck cancer. Nat Rev Cancer, 11, 9-22.

LEWIN, F., NORELL, S. E., JOHANSSON, H., GUSTAVSSON, P., WENNERBERG, J., BIORKLUND, A. \& RUTQVIST, L. E. 1998. Smoking tobacco, oral snuff, and alcohol in the etiology of squamous cell carcinoma of the head and neck: a populationbased case-referent study in Sweden. Cancer, 82, 1367-75.

LI, G., QIU, Y., SU, Z., REN, S., LIU, C., TIAN, Y. \& LIU, Y. 2013. Genome-wide analyses of radioresistance-associated miRNA expression profile in nasopharyngeal carcinoma using next generation deep sequencing. PLoS One, 8, e84486.

LI, X., XU, Q., WU, Y., LI, J., TANG, D., HAN, L. \& FAN, Q. 2014. A CCL2/ROS autoregulation loop is critical for cancer-associated fibroblasts-enhanced tumor growth of oral squamous cell carcinoma. Carcinogenesis, 35, 1362-1370.

LIANG, Y. J., LIU, H. C., SU, Y. X., ZHANG, T. H., CHU, M., LIANG, L. Z. \& LIAO, G. Q. 2011. Foxp3 expressed by tongue squamous cell carcinoma cells correlates with clinicopathologic features and overall survival in tongue squamous cell carcinoma patients. Oral Oncol, 47, 566-70.

LICHTENSTEIN, P., HOLM, N. V., VERKASALO, P. K., ILIADOU, A., KAPRIO, J., KOSKENVUO, M., PUKKALA, E., SKYTTHE, A. \& HEMMINKI, K. 2000.

Environmental and heritable factors in the causation of cancer--analyses of cohorts of twins from Sweden, Denmark, and Finland. N Engl J Med, 343, 78-85.

LIU, C. J., KAO, S. Y., TU, H. F., TSAI, M. M., CHANG, K. W. \& LIN, S. C. 2010. Increase of microRNA miR-31 level in plasma could be a potential marker of oral cancer. Oral Dis, 16, 360-4.

LJUBOJEVIC, S. \& SKERLEV, M. 2014. HPV-associated diseases. Clin Dermatol, 32, 227 34.

MAGGIONI, D., PIGNATARO, L. \& GARAVELLO, W. 2017. T-helper and T-regulatory cells modulation in head and neck squamous cell carcinoma. Oncoimmunology, 6, e1325066.

MANTOVANI, A., ALLAVENA, P., SICA, A. \& BALKWILL, F. 2008. Cancer-related inflammation. Nature, 454, 436-44.

MAPARA, M. Y. \& SYKES, M. 2004. Tolerance and cancer: mechanisms of tumor evasion and strategies for breaking tolerance. J Clin Oncol, 22, 1136-51. 
MARTINOVIC, I., ABEGUNEWARDENE, N., SEUL, M., VOSSELER, M., HORSTICK, G., BUERKE, M., DARIUS, H. \& LINDEMANN, S. 2005. Elevated monocyte chemoattractant protein-1 serum levels in patients at risk for coronary artery disease. Circ J, 69, 1484-9.

MASOPUST, D. \& SCHENKEL, J. M. 2013. The integration of T cell migration, differentiation and function. Nat Rev Immunol, 13, 309-20.

MASUCCI, G. V., CESANO, A., HAWTIN, R., JANETZKI, S., ZHANG, J., KIRSCH, I., DOBBIN, K. K., ALVAREZ, J., ROBBINS, P. B., SELVAN, S. R., STREICHER, H. Z., BUTTERFIELD, L. H. \& THURIN, M. 2016. Validation of biomarkers to predict response to immunotherapy in cancer: Volume I - pre-analytical and analytical validation. J Immunother Cancer, 4, 76.

MATTHIAS, C., HARRÉUS, U. \& STRANGE, R. 2006. Influential factors on tumor recurrence in head and neck cancer patients. European Archives of Oto-RhinoLaryngology and Head \& Neck, 263, 37-42.

MAYNE, S. T., CARTMEL, B., KIRSH, V. \& GOODWIN, W. J., JR. 2009. Alcohol and tobacco use prediagnosis and postdiagnosis, and survival in a cohort of patients with early stage cancers of the oral cavity, pharynx, and larynx. Cancer epidemiology, biomarkers \& prevention : a publication of the American Association for Cancer Research, cosponsored by the American Society of Preventive Oncology, 18, 33683374.

MELERO, I., ROUZAUT, A., MOTZ, G. T. \& COUKOS, G. 2014. T-cell and NK-cell infiltration into solid tumors: a key limiting factor for efficacious cancer immunotherapy. Cancer discovery, 4, 522-526.

MILLRUD, C. R., MANSSON KVARNHAMMAR, A., UDDMAN, R., BJORNSSON, S., RIESBECK, K. \& CARDELL, L. O. 2012. The activation pattern of blood leukocytes in head and neck squamous cell carcinoma is correlated to survival. PLoS One, 7, e51120.

MOCELLIN, S. \& NITTI, D. 2008. TNF and cancer: the two sides of the coin. Front Biosci, $13,2774-83$.

MOJIC, M., TAKEDA, K. \& HAYAKAWA, Y. 2017. The Dark Side of IFN- $\gamma$ : Its Role in Promoting Cancer Immunoevasion. International journal of molecular sciences, 19, 89.

MUCCI, L. A., HJELMBORG, J. B., HARRIS, J. R., CZENE, K., HAVELICK, D. J., SCHEIKE, T., GRAFF, R. E., HOLST, K., MOLLER, S., UNGER, R. H., MCINTOSH, C., NUTTALL, E., BRANDT, I., PENNEY, K. L., HARTMAN, M., KRAFT, P., PARMIGIANI, G., CHRISTENSEN, K., KOSKENVUO, M., HOLM, N. V., HEIKKILA, K., PUKKALA, E., SKYTTHE, A., ADAMI, H. O. \& KAPRIO, J. 2016. Familial Risk and Heritability of Cancer Among Twins in Nordic Countries. Jama, 315, 68-76.

NAGARSHETH, N., WICHA, M. S. \& ZOU, W. 2017. Chemokines in the cancer microenvironment and their relevance in cancer immunotherapy. Nat Rev Immunol, 17, 559-572.

NGAN, H. L., WANG, L., LO, K. W. \& LUI, V. W. Y. 2018. Genomic Landscapes of EBVAssociated Nasopharyngeal Carcinoma vs. HPV-Associated Head and Neck Cancer. Cancers (Basel), 10. 
NOGUEIRA, G. A. S., COSTA, E. F. D., LOPES-AGUIAR, L., LIMA, T. R. P., VISACRI, M. B., PINCINATO, E. C., LOURENCO, G. J., CALONGA, L., MARIANO, F. V., ALTEMANI, A., ALTEMANI, J. M. C., MORIEL, P., CHONE, C. T., RAMOS, C. D. \& LIMA, C. S. P. 2018. Polymorphisms in DNA mismatch repair pathway genes predict toxicity and response to cisplatin chemoradiation in head and neck squamous cell carcinoma patients. Oncotarget, 9, 29538-29547.

O'RORKE, M. A., ELLISON, M. V., MURRAY, L. J., MORAN, M., JAMES, J. \& ANDERSON, L. A. 2012. Human papillomavirus related head and neck cancer survival: a systematic review and meta-analysis. Oral Oncol, 48, 1191-201.

OLIVETO, S., MANCINO, M., MANFRINI, N. \& BIFFO, S. 2017. Role of microRNAs in translation regulation and cancer. World $\mathrm{J}$ Biol Chem, 8, 45-56.

PARKIN, D. M. \& BRAY, F. 2006. Chapter 2: The burden of HPV-related cancers. Vaccine, 24 Suppl 3, S3/11-25.

PASQUALETTI, F., BOCCI, G., MEY, V., MENGHINI, V., MONTRONE, S., COCUZZA, P., FERRAZZA, P., SECCIA, V., DELISHAJ, D., ORLANDINI, C., FABRINI, M. G. \& DANESI, R. 2015. Akt1 rs2498801 is related to survival in head and neck squamous cell cancer treated with radiotherapy. Anticancer Res, 35, 269-71.

PEREA-MILLA LOPEZ, E., MINARRO-DEL MORAL, R. M., MARTINEZ-GARCIA, C., ZANETTI, R., ROSSO, S., SERRANO, S., ANEIROS, J. F., JIMENEZ-PUENTE, A. \& REDONDO, M. 2003. Lifestyles, environmental and phenotypic factors associated with lip cancer: a case-control study in southern Spain. Br J Cancer, 88, 1702-7.

PETER, F., WITTEKINDT, C., FINKENSIEPER, M., KIEHNTOPF, M. \& GUNTINASLICHIUS, O. 2013. Prognostic impact of pretherapeutic laboratory values in head and neck cancer patients. J Cancer Res Clin Oncol, 139, 171-8.

PETERSEN, R. P., CAMPA, M. J., SPERLAZZA, J., CONLON, D., JOSHI, M. B., HARPOLE, D. H., JR. \& PATZ, E. F., JR. 2006. Tumor infiltrating Foxp3+ regulatory T-cells are associated with recurrence in pathologic stage I NSCLC patients. Cancer, 107, 2866-72.

PFEIFER, G. P., DENISSENKO, M. F., OLIVIER, M., TRETYAKOVA, N., HECHT, S. S. \& HAINAUT, P. 2002. Tobacco smoke carcinogens, DNA damage and p53 mutations in smoking-associated cancers. Oncogene, 21, 7435-51.

POH, A. R. \& ERNST, M. 2018. Targeting Macrophages in Cancer: From Bench to Bedside. Frontiers in oncology, 8, 49-49.

RACHIDI, S., WALLACE, K., WRANGLE, J. M., DAY, T. A., ALBERG, A. J. \& LI, Z. 2016. Neutrophil-to-lymphocyte ratio and overall survival in all sites of head and neck squamous cell carcinoma. Head Neck, 38 Suppl 1, E1068-74.

RASSOULI, A., SALIBA, J., CASTANO, R., HIER, M. \& ZEITOUNI, A. G. 2015. Systemic inflammatory markers as independent prognosticators of head and neck squamous cell carcinoma. Head Neck, 37, 103-10.

REIS, P. P., TOMENSON, M., CERVIGNE, N. K., MACHADO, J., JURISICA, I., PINTILIE, M., SUKHAI, M. A., PEREZ-ORDONEZ, B., GRENMAN, R., GILBERT, R. W., GULLANE, P. J., IRISH, J. C. \& KAMEL-REID, S. 2010. Programmed cell death 4 loss increases tumor cell invasion and is regulated by miR21 in oral squamous cell carcinoma. Mol Cancer, 9, 238.

RENTOFT, M., COATES, P. J., LOLJUNG, L., WILMS, T., LAURELL, G. \& NYLANDER, K. 2014. Expression of CXCL10 is associated with response to radiotherapy and overall survival in squamous cell carcinoma of the tongue. Tumor Biology, 35, 4191-4198.

RETTIG, E. M. \& D'SOUZA, G. 2015. Epidemiology of head and neck cancer. Surg Oncol Clin N Am, 24, 379-96. 
RIVELLI, V., LUEBBERS, H. T., WEBER, F. E., CORDELLA, C., GRÄTZ, K. W. \& KRUSE, A. L. 2011. Screening recurrence and lymph node metastases in head and neck cancer: the role of computer tomography in follow-up. Head \& neck oncology, 3 , 18-18.

ROSENQUIST, K., WENNERBERG, J., SCHILDT, E. B., BLADSTROM, A., GORAN HANSSON, B. \& ANDERSSON, G. 2005. Oral status, oral infections and some lifestyle factors as risk factors for oral and oropharyngeal squamous cell carcinoma. A population-based case-control study in southern Sweden. Acta Otolaryngol, 125, 1327-36.

ROTHSCHILD, U., MULLER, L., LECHNER, A., SCHLOSSER, H. A., BEUTNER, D., LAUBLI, H., ZIPPELIUS, A. \& ROTHSCHILD, S. I. 2018. Immunotherapy in head and neck cancer - scientific rationale, current treatment options and future directions. Swiss Med Wkly, 148, w14625.

RUFFELL, B., DENARDO, D. G., AFFARA, N. I. \& COUSSENS, L. M. 2010. Lymphocytes in cancer development: polarization towards pro-tumor immunity. Cytokine \& growth factor reviews, 21, 3-10.

RUSSELL, S., ANGELL, T., LECHNER, M., LIEBERTZ, D., CORREA, A., SINHA, U., KOKOT, N. \& EPSTEIN, A. 2013. Immune cell infiltration patterns and survival in head and neck squamous cell carcinoma. Head Neck Oncol, 5, 24.

SAEED, S., MAHJABEEN, I., SARWAR, R., BASHIR, K. \& KAYANI, M. A. 2017. Haplotype analysis of XRCC2 gene polymorphisms and association with increased risk of head and neck cancer. Scientific Reports, 7, 13210.

SANO, D. \& ORIDATE, N. 2016. The molecular mechanism of human papillomavirusinduced carcinogenesis in head and neck squamous cell carcinoma. Int J Clin Oncol, 21, 819-826.

SCAPOLI, L., PALMIERI, A., LO MUZIO, L., PEZZETTI, F., RUBINI, C., GIRARDI, A., FARINELLA, F., MAZZOTTA, M. \& CARINCI, F. 2010. MicroRNA expression profiling of oral carcinoma identifies new markers of tumor progression. Int $J$ Immunopathol Pharmacol, 23, 1229-34.

SCHILDT, E. B., ERIKSSON, M., HARDELL, L. \& MAGNUSON, A. 1998. Oral snuff, smoking habits and alcohol consumption in relation to oral cancer in a Swedish casecontrol study. Int J Cancer, 77, 341-6.

SCOTT, M. G. 2010. When do new biomarkers make economic sense? Scand J Clin Lab Invest Suppl, 242, 90-5.

SHANG, B., LIU, Y., JIANG, S. J. \& LIU, Y. 2015. Prognostic value of tumor-infiltrating FoxP3+ regulatory T cells in cancers: a systematic review and meta-analysis. Sci Rep, $5,15179$.

SHARMA, K. H., SHAH, K. H., PATEL, I., PATEL, A. K. \& CHAUDHARI, S. 2015. Do circulating blood cell types correlate with modifiable risk factors and outcomes in patients with acute coronary syndrome (ACS)? Indian Heart J, 67, 444-51.

SHARP, L., MCDEVITT, J., CARSIN, A. E., BROWN, C. \& COMBER, H. 2014. Smoking at diagnosis is an independent prognostic factor for cancer-specific survival in head and neck cancer: findings from a large, population-based study. Cancer Epidemiol Biomarkers Prev, 23, 2579-90.

SHIAO, S. L., GANESAN, A. P., RUGO, H. S. \& COUSSENS, L. M. 2011. Immune microenvironments in solid tumors: new targets for therapy. Genes Dev, 25, 2559-72.

SIMARD, E. P., TORRE, L. A. \& JEMAL, A. 2014. International trends in head and neck cancer incidence rates: differences by country, sex and anatomic site. Oral Oncol, 50, 387-403. 
SOKOL, C. L. \& LUSTER, A. D. 2015. The chemokine system in innate immunity. Cold Spring Harbor perspectives in biology, 7, a016303.

SPIRA, A., BEANE, J., SHAH, V., LIU, G., SCHEMBRI, F., YANG, X., PALMA, J. \& BRODY, J. S. 2004. Effects of cigarette smoke on the human airway epithelial cell transcriptome. Proc Natl Acad Sci U S A, 101, 10143-8.

SPRAGUE, B. L., TRENTHAM-DIETZ, A., KLEIN, B. E., KLEIN, R., CRUICKSHANKS, K. J., LEE, K. E. \& HAMPTON, J. M. 2008. Physical activity, white blood cell count, and lung cancer risk in a prospective cohort study. Cancer Epidemiol Biomarkers Prev, 17, 2714-22.

SPRANGER, S. \& GAJEWSKI, T. F. 2016. Tumor-intrinsic oncogene pathways mediating immune avoidance. Oncoimmunology, 5, e1086862.

STANLEY, M. 2006. Immune responses to human papillomavirus. Vaccine, 24, S16-S22.

STEEMERS, F. J., CHANG, W., LEE, G., BARKER, D. L., SHEN, R. \& GUNDERSON, K. L. 2006. Whole-genome genotyping with the single-base extension assay. Nature Methods, 3, 31-33.

STURGIS, E. M. \& CINCIRIPINI, P. M. 2007. Trends in head and neck cancer incidence in relation to smoking prevalence: an emerging epidemic of human papillomavirusassociated cancers? Cancer, 110, 1429-35.

STÄMPFLI, M. R. \& ANDERSON, G. P. 2009. How cigarette smoke skews immune responses to promote infection, lung disease and cancer. Nature Reviews Immunology, 9, 377.

SUN, Y. M., LIN, K. Y. \& CHEN, Y. Q. 2013. Diverse functions of miR-125 family in different cell contexts. J Hematol Oncol, 6, 6.

SWEDISH HEAD AND NECK CANCER REGISTER 2018. Huvud- och halscancer, Årsrapport nationellt kvalitetsregister, 2018, Diagnosår: 2008-2017, Svensk kvalitetsregister för huvud- och halscancer, Regionalt Cancercentrum Väst, Göteborg, Sweden.

SVORONOS, A. A., ENGELMAN, D. M. \& SLACK, F. J. 2016. OncomiR or Tumor Suppressor? The Duplicity of MicroRNAs in Cancer. Cancer Res, 76, 3666-70.

SYRJANEN, K., SYRJANEN, S., LAMBERG, M., PYRHONEN, S. \& NUUTINEN, J. 1983. Morphological and immunohistochemical evidence suggesting human papillomavirus (HPV) involvement in oral squamous cell carcinogenesis. Int J Oral Surg, 12, 418-24.

TALHOUT, R., SCHULZ, T., FLOREK, E., VAN BENTHEM, J., WESTER, P. \& OPPERHUIZEN, A. 2011. Hazardous compounds in tobacco smoke. International journal of environmental research and public health, 8, 613-628.

TEZAL, M., SCANNAPIECO, F. A., WACTAWSKI-WENDE, J., HYLAND, A., MARSHALL, J. R., RIGUAL, N. R. \& STOLER, D. L. 2012. Local inflammation and human papillomavirus status of head and neck cancers. Arch Otolaryngol Head Neck Surg, 138, 669-75.

TOMASETTI, C., LI, L. \& VOGELSTEIN, B. 2017. Stem cell divisions, somatic mutations, cancer etiology, and cancer prevention. Science, 355, 1330-1334.

TREFFERS, L. W., HIEMSTRA, I. H., KUIJPERS, T. W., VAN DEN BERG, T. K. \& MATLUNG, H. L. 2016. Neutrophils in cancer. Immunol Rev, 273, 312-28.

TSAI, M. H., LIN, C. D., HSIEH, Y. Y., CHANG, F. C., TSAI, F. J., CHEN, W. C. \& TSAI, C. H. 2002. Prognostic significance of the proline form of p53 codon 72 polymorphism in nasopharyngeal carcinoma. Laryngoscope, 112, 116-9. 
TULGAR, Y. K., CAKAR, S., TULGAR, S., DALKILIC, O., CAKIROGLU, B. \& UYANIK, B. S. 2016. The effect of smoking on neutrophil/lymphocyte and platelet/lymphocyte ratio and platelet indices: a retrospective study. Eur Rev Med Pharmacol Sci, 20, 3112-8.

U.S. DEPARTMENT OF HEALTH AND HUMAN SERVICES 2010. How Tobacco Smoke Causes Disease: The Biology and Behavioral Basis for Smoking-Attributable Disease: A Report of the Surgeon General. Atlanta (GA): Centers for Disease Control and Prevention (US).

UCHIYAMA, K., IWABUCHI, H., YAMADA, M., SUGIYAMA, K. \& NAKAYAMA, S. 2012. Digestive symptoms as side effects of combination chemotherapy of docetaxel, nedaplatin and 5-fluorouracil for head and neck cancer. Gan To Kagaku Ryoho, 39, 1659-64.

VAN DER SCHROEFF, M. P., DERKS, W., HORDIJK, G. J. \& DE LEEUW, R. J. 2007. The effect of age on survival and quality of life in elderly head and neck cancer patients: a long-term prospective study. Eur Arch Otorhinolaryngol, 264, 415-22.

VAN DER SCHROEFF, M. P., STEYERBERG, E. W., WIERINGA, M. H., LANGEVELD, T. P., MOLENAAR, J. \& BAATENBURG DE JONG, R. J. 2012. Prognosis: a variable parameter: dynamic prognostic modeling in head and neck squamous cell carcinoma. Head Neck, 34, 34-41.

VAN PARIJS, L. \& ABBAS, A. K. 1998. Homeostasis and self-tolerance in the immune system: turning lymphocytes off. Science, 280, 243-8.

VAN TIEL, E., PEETERS, P. H., SMIT, H. A., NAGELKERKE, N. J., VAN LOON, A. J., GROBBEE, D. E. \& BUENO-DE-MESQUITA, H. B. 2002. Quitting smoking may restore hematological characteristics within five years. Ann Epidemiol, 12, 378-88.

WANG, G., WANG, R., STRULOVICI-BAREL, Y., SALIT, J., STAUDT, M. R., AHMED, J., TILLEY, A. E., YEE-LEVIN, J., HOLLMANN, C., HARVEY, B.-G., KANER, R. J., MEZEY, J. G., SRIDHAR, S., PILLAI, S. G., HILTON, H., WOLFF, G., BITTER, H., VISVANATHAN, S., FINE, J. S., STEVENSON, C. S. \& CRYSTAL, R. G. 2015. Persistence of Smoking-Induced Dysregulation of MiRNA Expression in the Small Airway Epithelium Despite Smoking Cessation. PLOS ONE, 10, e0120824.

WANG, X. \& LIN, Y. 2008. Tumor necrosis factor and cancer, buddies or foes? Acta Pharmacol Sin, 29, 1275-88.

WARRINGTON, R., WATSON, W., KIM, H. L. \& ANTONETTI, F. R. 2011. An introduction to immunology and immunopathology. Allergy Asthma Clin Immunol, 7 Suppl 1, S1.

WHEELER, D. A., SRINIVASAN, M., EGHOLM, M., SHEN, Y., CHEN, L., MCGUIRE, A., HE, W., CHEN, Y. J., MAKHIJANI, V., ROTH, G. T., GOMES, X., TARTARO, K., NIAZI, F., TURCOTTE, C. L., IRZYK, G. P., LUPSKI, J. R., CHINAULT, C., SONG, X. Z., LIU, Y., YUAN, Y., NAZARETH, L., QIN, X., MUZNY, D. M., MARGULIES, M., WEINSTOCK, G. M., GIBBS, R. A. \& ROTHBERG, J. M. 2008. The complete genome of an individual by massively parallel DNA sequencing. Nature, 452, 872-6.

WIENCKE, J. K. 2002. DNA adduct burden and tobacco carcinogenesis. Oncogene, 21, 7376-91.

WILLINGER, C. M., RONG, J., TANRIVERDI, K., COURCHESNE, P. L., HUAN, T., WASSERMAN, G. A., LIN, H., DUPUIS, J., JOEHANES, R., JONES, M. R., CHEN, G., BENJAMIN, E. J., O'CONNOR, G. T., MIZGERD, J. P., FREEDMAN, J. E., LARSON, M. G. \& LEVY, D. 2017. MicroRNA Signature of Cigarette Smoking and Evidence for a Putative Causal Role of MicroRNAs in Smoking-Related Inflammation and Target Organ Damage. Circulation. Cardiovascular genetics, 10, e001678. 
WILSON, A. G., SYMONS, J. A., MCDOWELL, T. L., MCDEVITT, H. O. \& DUFF, G. W. 1997. Effects of a polymorphism in the human tumor necrosis factor alpha promoter on transcriptional activation. Proc Natl Acad Sci U S A, 94, 3195-9.

WITHAM, S., TAKANO, K., SCHWARTZ, C. \& ALEXOV, E. 2011. A missense mutation in CLIC2 associated with intellectual disability is predicted by in silico modeling to affect protein stability and dynamics. Proteins, 79, 2444-54.

VIVIER, E., RAULET, D. H., MORETTA, A., CALIGIURI, M. A., ZITVOGEL, L., LANIER, L. L., YOKOYAMA, W. M. \& UGOLINI, S. 2011. Innate or adaptive immunity? The example of natural killer cells. Science, 331, 44-9.

VOGELSTEIN, B. \& KINZLER, K. W. 2004. Cancer genes and the pathways they control. Nat Med, 10, 789-99.

VOKES, E. E., WEICHSELBAUM, R. R., LIPPMAN, S. M. \& HONG, W. K. 1993. Head and neck cancer. $N$ Engl $J$ Med, 328, 184-94.

WORLD HEALTH ORGANIZATION 2017. WHO report on the global tobacco epidemic, 2017: monitoring tobacco use and prevention policies. Geneva: World Health Organization.

WU, M.-Y., HUANG, S.-J., YANG, F., QIN, X.-T., LIU, D., DING, Y., YANG, S. \& WANG, X.-C. 2017. Detection of nasopharyngeal carcinoma susceptibility with single nucleotide polymorphism analysis using next-generation sequencing technology. Oncotarget, 8, 52708-52723.

WYSS, A. B., HASHIBE, M., LEE, Y.-C. A., CHUANG, S.-C., MUSCAT, J., CHEN, C., SCHWARTZ, S. M., SMITH, E., ZHANG, Z.-F., MORGENSTERN, H., WEI, Q., LI, G., KELSEY, K. T., MCCLEAN, M., WINN, D. M., SCHANTZ, S., YU, G.-P., GILLISON, M. L., ZEVALLOS, J. P., BOFFETTA, P. \& OLSHAN, A. F. 2016. Smokeless Tobacco Use and the Risk of Head and Neck Cancer: Pooled Analysis of US Studies in the INHANCE Consortium. American journal of epidemiology, 184, 703-716.

XIA, W. X., ZHANG, H. B., SHI, J. L., LU, X., WANG, L., YE, Y. F., CAO, K. J., QIAN, C. N., GUO, X. \& XIANG, Y. Q. 2013. A prognostic model predicts the risk of distant metastasis and death for patients with nasopharyngeal carcinoma based on pretreatment serum C-reactive protein and N-classification. Eur J Cancer, 49, 2152-60.

XU, F. H., XIONG, D., XU, Y. F., CAO, S. M., XUE, W. Q., QIN, H. D., LIU, W. S., CAO, J. Y., ZHANG, Y., FENG, Q. S., CHEN, L. Z., LI, M. Z., LIU, Z. W., LIU, Q., HONG, M. H., SHUGART, Y. Y., ZENG, Y. X., ZENG, M. S. \& JIA, W. H. 2012. An epidemiological and molecular study of the relationship between smoking, risk of nasopharyngeal carcinoma, and Epstein-Barr virus activation. J Natl Cancer Inst, 104, 1396-410.

XUE, X., LIU, Y., WANG, Y., MENG, M., WANG, K., ZANG, X., ZHAO, S., SUN, X., CUI, L., PAN, L. \& LIU, S. 2016. MiR-21 and MiR-155 promote non-small cell lung cancer progression by downregulating SOCS1, SOCS6, and PTEN. Oncotarget, 7, 84508-84519.

ZAHOREC, R. 2001. Ratio of neutrophil to lymphocyte counts--rapid and simple parameter of systemic inflammation and stress in critically ill. Bratisl Lek Listy, 102, 5-14.

ZHANG, J. M. \& AN, J. 2007. Cytokines, inflammation, and pain. Int Anesthesiol Clin, 45, 27-37.

ZHANG, L., LIU, S.-H., WRIGHT, T. T., SHEN, Z.-Y., LI, H.-Y., ZHU, W., POTEMPA, L. A., JI, S.-R., SZALAI, A. J. \& WU, Y. 2015. C-reactive protein directly suppresses Th1 cell differentiation and alleviates experimental autoimmune encephalomyelitis. Journal of immunology (Baltimore, Md. : 1950), 194, 5243-5252. 
ZHANG, Y. L., LI, J., MO, H. Y., QIU, F., ZHENG, L. M., QIAN, C. N. \& ZENG, Y. X. 2010. Different subsets of tumor infiltrating lymphocytes correlate with NPC progression in different ways. Mol Cancer, 9, 4. 


\section{Papers}

The papers associated with this thesis have been removed for copyright reasons. For more details about these see:

http://urn.kb.se/resolve?urn=urn:nbn:se:liu:diva-162097 


\section{FACULTY OF MEDICINE AND HEALTH SCIENCES}

Linköping University Medical Dissertation No. 1719, 2019

Department of Clinical and Experimental Medicine

Linköping University

SE-581 83 Linköping, Sweden

www.liu.se 